\title{
Simultaneous adsorption of quinoline and dibenzothiophene over Ni-based mesoporous materials at different $\mathrm{Si} / \mathrm{Al}$ ratio
}

\author{
L. Alvarado-Perea ${ }^{\mathrm{a}}$, J.A. Colín-Luna ${ }^{\mathrm{b}}$, A. López-Gaona ${ }^{\mathrm{c}}$, Tanya Wolff ${ }^{\mathrm{d}}$, J.G. Pacheco-Sosa ${ }^{\mathrm{e}}$, \\ J.C. García-Martínez ${ }^{\text {b,* }}$ \\ ${ }^{a}$ Universidad Autónoma de Zacatecas, Unidad Académica de Ciencias Químicas y Maestría en Ciencias de la Ingeniería, Campus UAZ Siglo XXI, Carretera Zacatecas- \\ Guadalajara km 6, Ejido La Escondida, CP. 98160, Zacatecas, Mexico \\ ${ }^{\mathrm{b}}$ Universidad Autónoma Metropolitana Azcapotzalco, Departamento de Energía, Área de Análisis de Procesos, Av. San Pablo 180, Col. Reynosa, CP. 02200, CDMX, \\ Mexico \\ ${ }^{\mathrm{c}}$ Universidad Autónoma Metropolitana Iztapalapa, Departamento De Química, Av. San Rafael Atlixco 186, Col. Vicentina, CP. 09340, CDMX, Mexico \\ ${ }^{\mathrm{d}}$ Max Planck Institute for Dynamics of Complex Technical Systems, Sandtorstr. 1, 39106, Magdeburg, Germany \\ e Universidad Juárez Autónoma de Tabasco (UJAT), División Académica de Ciencias Básicas, Km 1, Carretera Cunduacán-Jalpa de Méndez, Col. La Esmeralda, CP. 8669, \\ Cunduacán, Tabasco, Mexico
}

\section{A R T I C L E I N F O}

\section{Keywords:}

Dibenzothiophene

Quinoline

Lewis acid sites

Selectivity

Adsorption kinetics

\begin{abstract}
A B S T R A C T
In this study, two mesoporous materials such as MCM-41 and Ni/MCM-41 were modified with $\mathrm{Al}$ at different $\mathrm{Si} /$ $\mathrm{Al}$ ratios. The mesoporous materials were proved as sorbents of heterocyclic nitrogen and sulfur compounds employing quinoline (Q) and dibenzothiophene (DBT), respectively, as model molecules of that precursor pollutants at the same concentrations of ppmw of nitrogen and sulfur (N:S = 1 ratio). The sample with the highest $\mathrm{Si} / \mathrm{Al}$ ratio showed the highest specific surface, and at low $\mathrm{Si} / \mathrm{Al}$ decreased the specific surface. With X-ray diffraction (XRD) the Ni containing in MCM-41, there is a clear trend and the highly hexagonal ordered sample is the one without $\mathrm{Al}$ and once the $\mathrm{Al}$ is added, the hexagonal ordering is highly modified. Employing $\mathrm{NH}_{3}-\mathrm{TPD}_{\text {and }}$ $\mathrm{NMR}$ revealed that the samples with $\mathrm{Si} / \mathrm{Al}=5$ and 16 have higher Lewis acid sites than another ratio of $\mathrm{Si} / \mathrm{Al}$. The modification successfully added small amounts of $\mathrm{Ni}$ that did not collapse the pore structure but increased the density of surface (acidic) groups that in turn favored the uptake of the sulfur compound through $\pi$-complexation adsorption mechanism. It is also possible to recognize that the samples with a Si/Al ratio of 5 and 16 revealed the presence of the highest surface density of weak acid sites for both sorbents. Adsorption experiments were carried out in a batch adsorption system at $313 \mathrm{~K}$ and atmospheric pressure using a model mixture from diesel containing: DBT, Q, and $40 \mathrm{ml}$ of dodecane. The sulfur adsorption was substantially improved when Ni was incorporated to MCM-41; for example, at $250 \mathrm{ppmw}$ of $\mathrm{N}$ uptake of DBT was almost twice than MCM-41 alone. This result would indicate that Ni/MCM-41 could remove both molecules but mainly the nitrogen molecule at high concentrations. The Langmuir and Freundlich adsorption isotherms were used for all materials considering $\mathrm{Q}$ in the presence of DBT depending on the Si/Al ratio. This behavior did not happen for the DBT whose behavior was modelled by an isotherm of the Freundlich type for Ni/MCM-41 and adsorbed in acid sites and multilayer. Lastly, experimental results indicated that MCM-41 with $\mathrm{Si} / \mathrm{Al}=\infty$ has the highest $(\mathrm{Q} / \mathrm{DBT})$ selectivity of 13,390 at $50 \mathrm{ppmw} \mathrm{N}$ compared to another Si/Al ratio, for example, at $250 \mathrm{ppmw}$ N.
\end{abstract}

\section{Introduction}

Despite new energy sources (biodiesel, bioethanol, green diesel, and others) less contaminants than fossil fuels [1,2], the world faces the challenge to cover the demand for automotive fuels that could not be reached only with fuels from biomass [2]. This has led to the refiners to improve their processes to achieve high production of gasoline and diesel, taking care of the rigorous environmental regulations regarding the sulfur content $(<10 \mathrm{ppm})$ in diesel fuels. The typical process to reach low sulfur levels is through the hydrodesulfurization (HDS) reaction, employing a sulfured catalyst usually Co-MoS or Ni-MoS supported on alumina at severe conditions of temperatures ( $>573 \mathrm{~K}$ ) and hydrogen pressures ( $>5.5 \mathrm{MPa}$ ) [3]. The severe-operating conditions, high hydrogen consumption and considering that organo nitrogenated

\footnotetext{
* Corresponding author.

E-mail address: jgarciam@azc.uam.mx (J.C. García-Martínez).
} 
molecules contained in the diesel cuts deactivate the catalyst, making the process unaffordable.

An alternative process to reach the stringent environmental legislation regarding sulfur content, is using adsorption of organo-compounds employing functionalized mesoporous materials before HDS [4-7]. This kind of process has the advantage of being carried out at temperatures below of $353 \mathrm{~K}$, atmospheric pressure and does not require hydrogen consumption. The crucial part of the process is the kind of adsorbent material employed because the adsorption of the sulfur and nitrogenous molecules would depend on the physicochemical and textural properties of the adsorbent [6-8]. Zeolites [5,9-13], activated carbons [14-20], activated alumina, metal oxides, and mixed oxide [8,21-25] are the most common adsorbents. Although the choice of these materials should be made considering adsorption capacity, selectivity, regenerability, lifetime, and price, some properties must be considered. For instance, activated carbons have shown that not only their high specific area and the highest polarity are the cause of the removal of N-compounds that activated alumina, but also their high oxygen groups density and acidic functional groups. Almarri et al. [15] and Arcibar-Orozco et al. [18] found that carboxyl and carboxylic anhydride groups are acidic functional groups contributed to adsorption of $\mathrm{Q}$, whereas primary basic oxygen-containing groups, such as carbonyl and quinone groups, contributed to adsorption of indole and followed the order in terms of more favorable adsorption: Indole $>$ $\mathrm{Q}>$ 4,6-dymethildibenzothiophene (4,6-DMDBT) > DBT. Moreover, the activated carbons have larger surface areas $\left(>1000 \mathrm{~m}^{2} / \mathrm{g}\right)$ but a microporous network that would limit the adsorption of large sulfur molecules such as dibenzothiophenes or alkyl dibenzothiophenes, like 4,6-DMDBT commonly contained in diesel cuts. Besides, activated carbons can form small particles or fines due to their low mechanical resistance causing high-pressure drops in continuous adsorption processes. These drawbacks restrict their use in industrial processes [4].

Zeolites are reported as adsorbents highly sulfur-selective employed commonly to adsorb sulfur compounds and have pore diameters from microporous order and surface areas lower than $\left(800 \mathrm{~m}^{2} / \mathrm{g}\right)$. There is an extensive broad consensus in the literature, that this high capacity and selectivity towards the sulfur compound is not only due to its acid properties but rather to the incorporation of metals $\left(\mathrm{Cu}^{+1}, \mathrm{Ag}^{+1}, \mathrm{Fe}^{+2}\right.$, $\mathrm{Zn}^{+2}, \mathrm{Cd}^{+2}, \mathrm{Mn}^{+2}$ or $\mathrm{Ni}^{+2}$ ) in the cavities of the zeolite $[7,13]$. It has been determined that $\mathrm{Cu}^{+1}$ is stronger than $\mathrm{Ag}^{+1}$ in the binding with sulfur and that this binding is by $\pi$-complexation. In this type of noncovalent interaction, there is a donation of electron charges from the orbital $\pi$ of the sulfur compound to the vacant s orbital of metals (known as $\sigma$ donation) and, simultaneously, a back-donation of electron charges from the $\mathrm{d}$ orbitals of metals to the orbital $\pi$ anti-bounding of the sulfur compound [5]. Most of the literature highlight $\mathrm{Cu}$ or $\mathrm{Ag}$ on zeolites [12]. Recently, Liao et al. [13] modify de acidic properties NaY zeolite using different concentrations of $\mathrm{NH}_{4} \mathrm{NO}_{3}(0.05-1.0 \mathrm{~mol} / \mathrm{L})$ solutions and different calcination temperatures (673-1023 K), Lewis acid sites bring on the adsorption of compounds containing conjugated $\pi$ bond as benzene and thiophene (Ti), whereas Brönsted acid site brings on the $\mathrm{Ti}$ are significant to determine the properties to remove sulfur compounds [15]. In the first synthesis, they found an equilibrium in the quantity of Lewis and Brönsted acidic sites, whereas calcination treatment generated Lewis acid sites, principally, due to the substitution of Al trivalent for tetravalent $\mathrm{Si}$ in the first treatment, and dehydroxylation in the second one [15]. An opposite effect was found in HY zeolites under calcination, where a decrease in sulfur removal occurred with the calcination temperature.

One possibility to remove sulfur compounds of larger sizes, as described above, is employing mesoporous silica materials with pores size larger than $3 \mathrm{~nm}$ and surfaces areas nearby to $1000 \mathrm{~m}^{2} / \mathrm{g}$ [23-26]. Recently, our group proved several kinds of mesoporous materials such as SBA-15, SBA-16, and MCM-41 as adsorbents of Q and DBT as model molecules representatives from diesel mixtures at $318 \mathrm{~K}$ and atmospheric pressure in a batch system and using different molecules
$[27,28]$. It was postulated that high surface area and $\mathrm{Si}-\mathrm{OH}$ groups (Brönsted acid sites) at that adsorption temperature, allowed selective adsorption of $\mathrm{Q}$ but weak adsorption of the sulfur molecule.

Therefore, in this paper is proposed to prove an MCM- 41 modified with $\mathrm{Al}$ at several $\mathrm{Si} / \mathrm{Al}$ ratios $(5,16,60,150$ and $\infty)$ and incorporating $\mathrm{Ni}$ on mesoporous silica in the adsorption of $\mathrm{Q}$ as the nitrogen molecule and DBT as a sulfur molecule in a mixture molecule from diesel. The influence of structural, textural, morphology and acidity of materials used was investigated to give a scientific explanation, were used at the same concentration of 50,100, 150200 and $250 \mathrm{ppmw}$ and $\mathrm{N}: \mathrm{S}=1$ ratio. A metal effect was shown to improve the adsorption sites of the sulfur molecule and selectivity.

\section{Experimental}

\subsection{Synthesis of MCM-41 and Ni/MCM-41 as adsorbents}

In this work, the synthesis of MCM-41 and Ni/MCM-41 with different amount of $\mathrm{Al}$ was carried out. These materials were prepared using the procedure reported by Alvarado-Perea et al. [29]. A typical procedure was performed as follows: tetrabutylammonium silicate was prepared with a mixture of $5.4 \mathrm{~g}$ of a solution of tetrabutylammonium hydroxide $40 \mathrm{wt} . \%$, and $0.6 \mathrm{~g}$ of silica fumed (both from Sigma Aldrich). The latter component was mixed with another solution formed by $3.4 \mathrm{~g}$ of cetyltrimethylammonium bromide, CTABr (Merck, CTABr $\geq$ $97 \%$ ) and $23.3 \mathrm{~g}$ of deionized water. The resultant mixture was stirred for $15 \mathrm{~min}$; at the end, the mixture had a molar composition of $1 \mathrm{SiO}_{2}$ : 0.35 CTABr: 0.31 TBAOH: $55 \mathrm{H}_{2} \mathrm{O}$. That mixture was transferred to a Nalgene bottle and aged for $48 \mathrm{~h}$ at $373 \mathrm{~K}$. The resultant solid was recovered by vacuum filtration and washed five times with $250 \mathrm{ml}$ of deionized water each time. The final powder was dried at $353 \mathrm{~K}$ for $6 \mathrm{~h}$. Finally, the solid obtained was heated up to $873 \mathrm{~K}$ in air at a heating rate of $5 \mathrm{~K} / \mathrm{min}$ and it was kept at this temperature for $6 \mathrm{~h}$. The Ni/ MCM-41 was prepared using the template ion exchange method [30]. In a typical essay, $3.0 \mathrm{~g}$ of synthesized MCM- 41 was mixed with $30 \mathrm{ml}$ of deionized water. To the previous mixture, $30 \mathrm{ml}$ of a solution $0.03 \mathrm{M}$ of $\mathrm{Ni}^{+2}$ was added dropwise under vigorous stirring. The Ni precursor was $\mathrm{Ni}\left(\mathrm{NO}_{3}\right)_{2} \cdot 6 \mathrm{H}_{2} \mathrm{O} \geq 99.0 \%$ from Merck. The resulting mixture was transferred into a Nalgene bottle and treated at $353 \mathrm{~K}$ for $20 \mathrm{~h}$ without stirring. The solid was recovered by vacuum filtration, washed with deionized water and dried at $353 \mathrm{~K}$ for $24 \mathrm{~h}$. The final product was calcinated at $873 \mathrm{~K}$ for $6 \mathrm{~h}$ in air and the heating rate was $5 \mathrm{~K} / \mathrm{min}$. The characterization of Ni/MCM-41 material was already published and discussed by Alvarado-Perea et al. [29], a brief description is presented below.

\subsection{Characterization of $M C M-41$}

\subsubsection{Structural analysis}

Powder X-ray diffraction (XRD) patterns were collected on an X'Pert PRO diffractometer by PANalytik using Ni-filtered CuKa radiation. The generator was operated with a voltage of $40 \mathrm{kV}$ and a current of $40 \mathrm{~mA}$. All samples were scanned in the small $2 \theta$ region $\left(1-10^{\circ}\right)$ with a step size of $0.016^{\circ}$ using a scanning time of $10 \mathrm{~s}$ per step.

\subsubsection{Textural analysis}

Nitrogen physisorption isotherms were measured at $-196^{\circ} \mathrm{C}$ using a Quantachrome Nova 2200 e analyzer. Specific surface areas were calculated from the linear region of BET plots while the total pore volume was evaluated using the amount adsorbed at a relative pressure of 0.995 .

\subsubsection{Transmission electron microscopy (TEM)}

The morphological TEM analysis was performed by using a Philips/ FEI CM200 microscope. The apparatus was operated at an acceleration voltage of $200 \mathrm{kV}$ and equipped with a CCD camera for the imaging 
acquisition and analySISpro SIS/ Olympus processing system.

\subsubsection{Temperature programmed desorption of Ammonia ( $\mathrm{NH}_{3}$-TPD)}

Surface acidity was investigated by Temperature Programmed Desorption of Ammonia experiments ( $\mathrm{NH}_{3}$-TPD). The samples were pretreated at $500{ }^{\circ} \mathrm{C}$ in helium for $2 \mathrm{~h}$, followed by cooling to $100^{\circ} \mathrm{C}$. Ammonia ( 1 vol.\% $\mathrm{NH}_{3}$ in $\mathrm{He}$ ) was then adsorbed at the same temperature for $2 \mathrm{~h}$. Physisorbed molecules were removed by switching back to a pure helium flow (also at $100^{\circ} \mathrm{C}$ ) for $1 \mathrm{~h}$. Finally, the temperature was raised to $650{ }^{\circ} \mathrm{C}$ with a heating rate of $10^{\circ} \mathrm{C} / \mathrm{min}$. Desorbed ammonia was detected with a TCD.

\subsection{5. ${ }^{29}$ Si and ${ }^{27}$ Al nuclear magnetic resonance (NMR)}

NMR spectra were recorded using a Bruker Avance 300 NMR spectrometer at room temperature. The ${ }^{29} \mathrm{Si}$ shifts were externally referenced to Q8M8. The ${ }^{27} \mathrm{Al}$ shifts scales were externally referenced to $\left[\mathrm{Al}\left(\mathrm{H}_{2} \mathrm{O}\right)_{6}\right]^{3+}$.

\subsection{Adsorption experiments}

Adsorption experiments were performed in jacketed glass containers at atmospheric pressure and $313 \mathrm{~K}$. All adsorbents were crushed and sieved at 100 mesh, the amount of adsorbent was of $0.2 \mathrm{~g}$, it is an optimal amount where there are no problems of mass transfer, external or internal experimentally it was verified. Also, several experiments have been performed and this quantity was determined as optimal, especially to prevent the solid from agglomerating in the liquid [27,28,31]. Adsorptive denitrogenation and desulfurization of model nitrogen and sulfur-containing compounds in dodecane were performed using the following adsorbents: MCM-41 and Ni/MCM-41 in batch mode. The nitrogen and sulfur concentrations were fixed between 0 and $250 \mathrm{ppmw}$ of $\mathrm{S}$ and $\mathrm{N}$ in $40 \mathrm{ml}$ of dodecane, with $\mathrm{N}: \mathrm{S}=1$ ratio. In each experiment, the mixture was stirred at $400 \mathrm{rpm}$, until complete homogenization, and at that instant $\left(\mathrm{t}_{0}\right)$, a sample was collected in a vial for further analysis in a capillary gas chromatograph brand Perkin-Elmer model Clarus 480, equipped with a capillary column (methylphenylsilicone, EC-5 ECONOCAP) and injector and flame ionization detector (FID) 200 and $250^{\circ} \mathrm{C}$, respectively. To achieve the separation of the organ compounds, two heating ramps were used in the oven. The first, from $160{ }^{\circ} \mathrm{C}$ until $200{ }^{\circ} \mathrm{C}$ for $2 \mathrm{~min}$ at a heat rate of $5 \mathrm{~K} / \mathrm{min}$ and the last one at 250 for $2 \mathrm{~min}$ at a heat rate of $20 \mathrm{~K} / \mathrm{min}$. The samples were collected every $5 \mathrm{~min}$ during the first hour and every $15 \mathrm{~min}$ for the next two hours; the sample volume was $0.3 \mathrm{~mL}$. The sampling process represents a reduction of the total volume by only around $10 \%$. All samples were filtered to avoid introducing the adsorbent to the gas chromatograph. The adsorption capacities of nitrogen and sulfur compounds ( $\mathrm{AC}_{\mathrm{S}}$ and $\mathrm{AC}_{\mathrm{N}}$, respectively) were obtained, such as described in a previous works $[27,28,31]$.

Sulfur and nitrogen removal were calculated through Eq. (1).

$\mathrm{AC}_{\mathrm{S}}$ or $\mathrm{AC}_{\mathrm{N}}(\%)=\frac{\left(\mathrm{C}_{0}-\mathrm{C}_{\mathrm{e}}\right)}{\mathrm{C}_{0}} \times 100$

Where $\mathrm{C}_{0}$ and $\mathrm{C}_{\mathrm{e}}$ represents the concentration in $\mathrm{mmol} \mathrm{L}^{-1}$ of sulfur of nitrogen compound at the initial time at the equilibrium, respectively.

Moreover, the selectivity was defined in terms of the ratio of adsorption and equilibrium concentration of $\mathrm{N} / \mathrm{S}$ ratio, according to Songolzadeh et al. [33], defined like:

$S=\frac{q_{N} / q_{S}}{C_{e, N} / C_{e, S}}$

\subsection{Adsorption kinetics}

Regarding the adsorption rate, the literature mentions several models that can be fitted to the experimental data. Azizian and Fallah
[32] made a review of these models. To understand the adsorption process, the commonly used kinetic models, the pseudo-second-order model was examined to describe the nitrogen adsorption kinetics of newly developed adsorbents. The pseudo-second-order model assumes that the rate-limiting step of a reaction may be chemisorption, which involves valence forces by electron sharing or electron exchange between the adsorbent and the adsorbate. This equation can be expressed as:

$\mathrm{r}=\frac{d q_{t}}{d t}=\mathrm{k}_{\mathrm{ads}}\left(q_{\mathrm{e}}-q_{\mathrm{t}}\right)^{2}$

$\frac{\mathrm{t}}{\mathrm{q}_{\mathrm{t}}}=\frac{1}{\mathrm{k}_{\text {ads }} \mathrm{q}_{\mathrm{e}}^{2}}+\frac{\mathrm{t}}{\mathrm{q}_{\mathrm{e}}}$

where $\mathrm{q}_{\mathrm{t}}(\mathrm{mmol} / \mathrm{g})$ is the amount adsorbed at each time (min), $\mathrm{k}_{\text {ads }}(\mathrm{g} /$ (mmol min)) is the adsorption rate constant of pseudo-second-order adsorption, and $\mathrm{r}$ is the adsorption rate. The slope and intercept of the linear plots of $t / q_{t}$ against $t$ yield the values of $\frac{1}{q_{e}}$ and $\frac{1}{k_{\text {ads }} q_{e}^{2}}$. The values of $\mathrm{q}_{\mathrm{e}}$ and $\mathrm{k}_{\mathrm{ads}}$ can be obtained from the slope and intercept.

\subsection{Adsorption isotherms}

The Langmuir isotherm is the most common model used to quantify the amount of adsorbate on the surface of the adsorbent as a function of partial pressure or concentration at a given temperature and occurs on the homogeneous surface with monolayer formation without any interaction. On the other hand, the Freundlich isotherm is an empirical equation employed to describe heterogeneous systems and multilayer adsorption and has been used for heterogeneous surface energy systems with the random distribution of sorption heat, the magnitude of the exponent $1 / \mathrm{n}$ indicates the variability of adsorption. For example, if $1 /$ $\mathrm{n}=1$, the adsorption is linear; this is the Henry's law behavior occurs, meanwhile $1 / \mathrm{n}>1$ represent favorable adsorption conditions and $1 /$ $\mathrm{n}<1$ an unfavorable adsorption also chemisorption process related to the adsorption capacity of the adsorbents and surface heterogeneity. The parameters of these isotherms were used in the same way by our group [27,28,31]. The results obtained with two adsorbents are presented in the next section.

\section{Results and discussion}

\subsection{Characterization of MCM-41 and Ni/MCM-41}

In this section it is presented the results of characterization of the materials used for the adsorption process.

\subsubsection{Structural analysis and textural analysis}

In this work, the characterization results of the MCM- 41 and $\mathrm{Ni}$ / MCM-41 materials varying the $\mathrm{Si} / \mathrm{Al}$ ratio were shown. In this way, the XRD patterns of the MCM- 41 and Ni/MCM- 41 with different Si/Al ratio are shown in Figs. 1 a and 2 a, respectively. As it is well known, MCM41 materials are characterized by typical diffractions (100), (110), (200) and (210) [34,35]. From the Fig.1a, it is possible to observe that there is not a clear trend of the patterns of the MCM-41 samples at different $\mathrm{Al}$ contents. For example, the case of MCM-41-Si/Al $=\infty$ (without $\mathrm{Al}$ ) did not show any characteristic peak at any value of $2 \theta$. However, the sample with at $\mathrm{Si} / \mathrm{Al}=150$ revealed the typical diffraction pattern of the MCM-41 materials. For the samples with higher $\mathrm{Al}$ content, the typical diffraction patterns of the MCM- 41 materials decreased because of the hard incorporation of the $\mathrm{Al}$ into the network of the materials. Based on the last results, it is concluded that these materials are poor hexagonal ordered. On the other hand, for the case of the Ni containing MCM-41, (Fig. 2a) we can see that there are a clear trend and the highly hexagonal ordered sample is the one without $\mathrm{Al}$ and once the $\mathrm{Al}$ is added the hexagonal ordering is highly modified. Besides, it seems that the method of the Ni incorporation improves the 

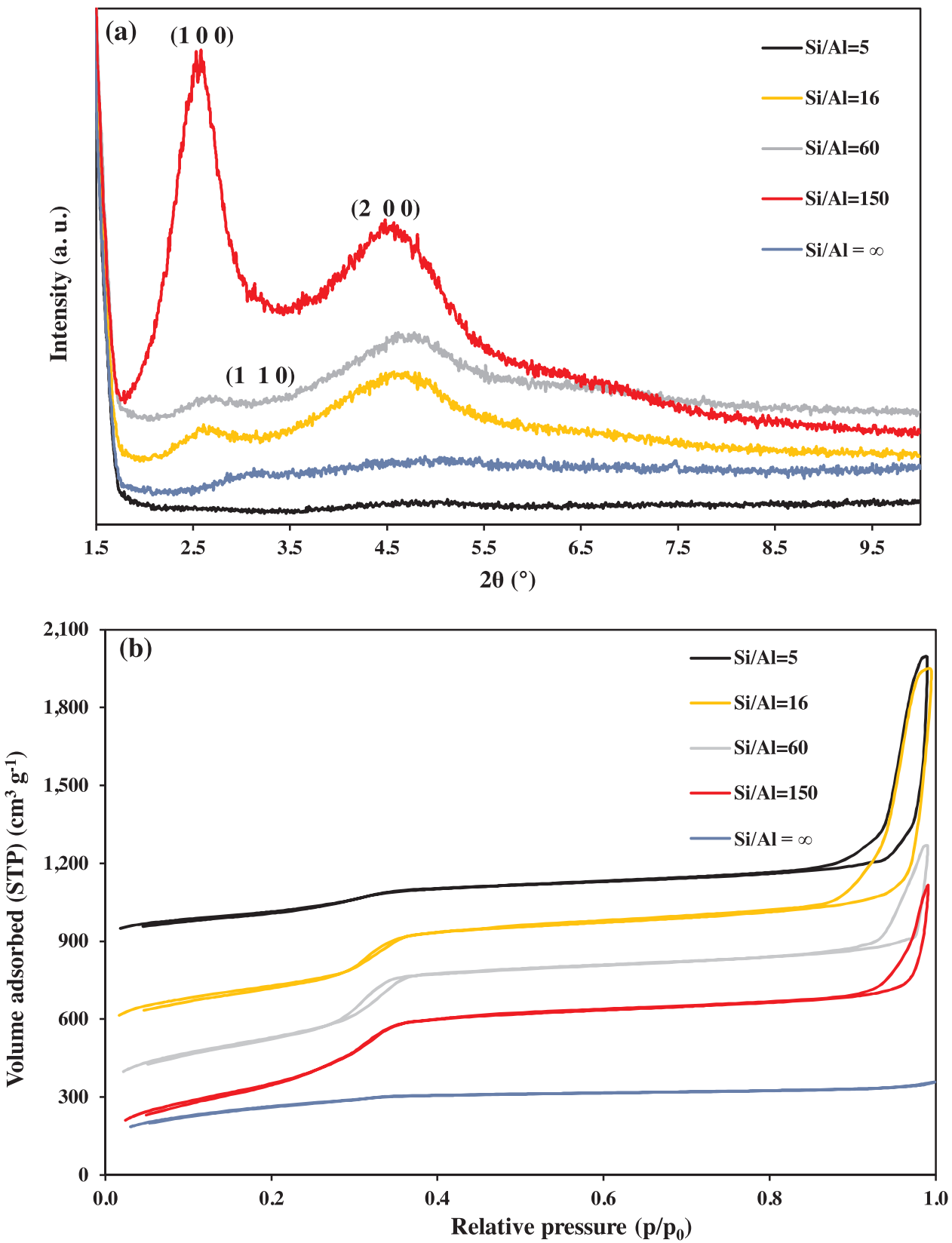

Fig. 1. (a) XRD patterns and (b) $\mathrm{N}_{2}$-physisorption isotherms of MCM-41 at different $\mathrm{Si} / \mathrm{Al}$ ratios.

ordering of MCM-41 materials [29]. These results it has already been shown by Yonemitsu et al. [30] whose found that the Ni impregnation method rearranges the pore structure of MCM-41. Based only on the $\mathrm{XRD}$ results, it is not possible to ensure that the structure of the materials does not correspond to the typical MCM-41 materials. For this reason, all materials were also characterized using $\mathrm{N}_{2}$-physisorption. Moreover, MCM-41 and Ni/MCM-41 materials are also characterized by a Type IV nitrogen isotherm, pore diameter in the range of mesoporous and by a high specific surface $[34,35]$. Fig. 1b and Fig. 2 b shows the adsorption isotherms and the adsorption data of the MCM-41 and $\mathrm{Ni}$ / MCM-4a with different $\mathrm{Si} / \mathrm{Al}$ ratios, respectively. These results revealed the presence of a type IV isotherm according to IUPAC classification for both adsorbents [36]. It is possible to observe that the $\mathrm{N}_{2}$ adsorption data do not depend strongly on the $\mathrm{Si} / \mathrm{Al}$ ratio of the MCM-41. Table 1 shows the results of the MCM-41 of BET specific surface, pore-volume and pore diameter, almost all samples presented a specific surface (around $1000 \mathrm{~m}^{2} \mathrm{~g}^{-1}$ ), and only the sample with the highest Al content $(\mathrm{Si} / \mathrm{Al}=5)$ had an important reduction of the specific surface $(554$ $\mathrm{m}^{2} \mathrm{~g}^{-1}$ ). An important modification of the pore volume was observed and the sample with a $\mathrm{Si} / \mathrm{Al}$ ratio of 16 showed the highest value $\left(2.31 \mathrm{~cm}^{3} \mathrm{~g}^{-1}\right)$. This modification might be caused by the high $\mathrm{Al}$ content in the materials. Additionally, in the same way than Table 1, the results of Ni/MCM-41 varying the $\mathrm{Si} / \mathrm{Al}$ are presented in Table 2 we can see that the highest value of specific surface was at $\mathrm{Si} / \mathrm{Al}=150$ $\left(1385 \mathrm{~m}^{2} \mathrm{~g}^{-1}\right)$ followed by $\mathrm{Si} / \mathrm{Al}=\infty\left(1087 \mathrm{~m}^{2} \mathrm{~g}^{-1}\right)$ [29], moreover the Ni incorporation into the MCM-41 network revealed just important modifications in the pore volume of the samples. In this case, the sample with a $\mathrm{Si} / \mathrm{Al}$ ratio of 150 showed the highest value $\left(2.0 \mathrm{~cm}^{3} \mathrm{~g}^{-1}\right)$.

\subsubsection{Transmission Electron Microscopy (TEM)}

To visualize the arrange and Ni effect on the morphology, TEM micrographs are shown in Fig. 3 for the samples; (a) MCM-41, (b) Ni/ MCM-41, (c) Ni/MCM-41 (Si/Al = 150) and (d) Ni/MCM-41 (Si/ $\mathrm{Al}=16$ ). In general, almost all adsorbents showed hexagonal pores arrange, which is characteristic of the MCM-41 materials. For the case 

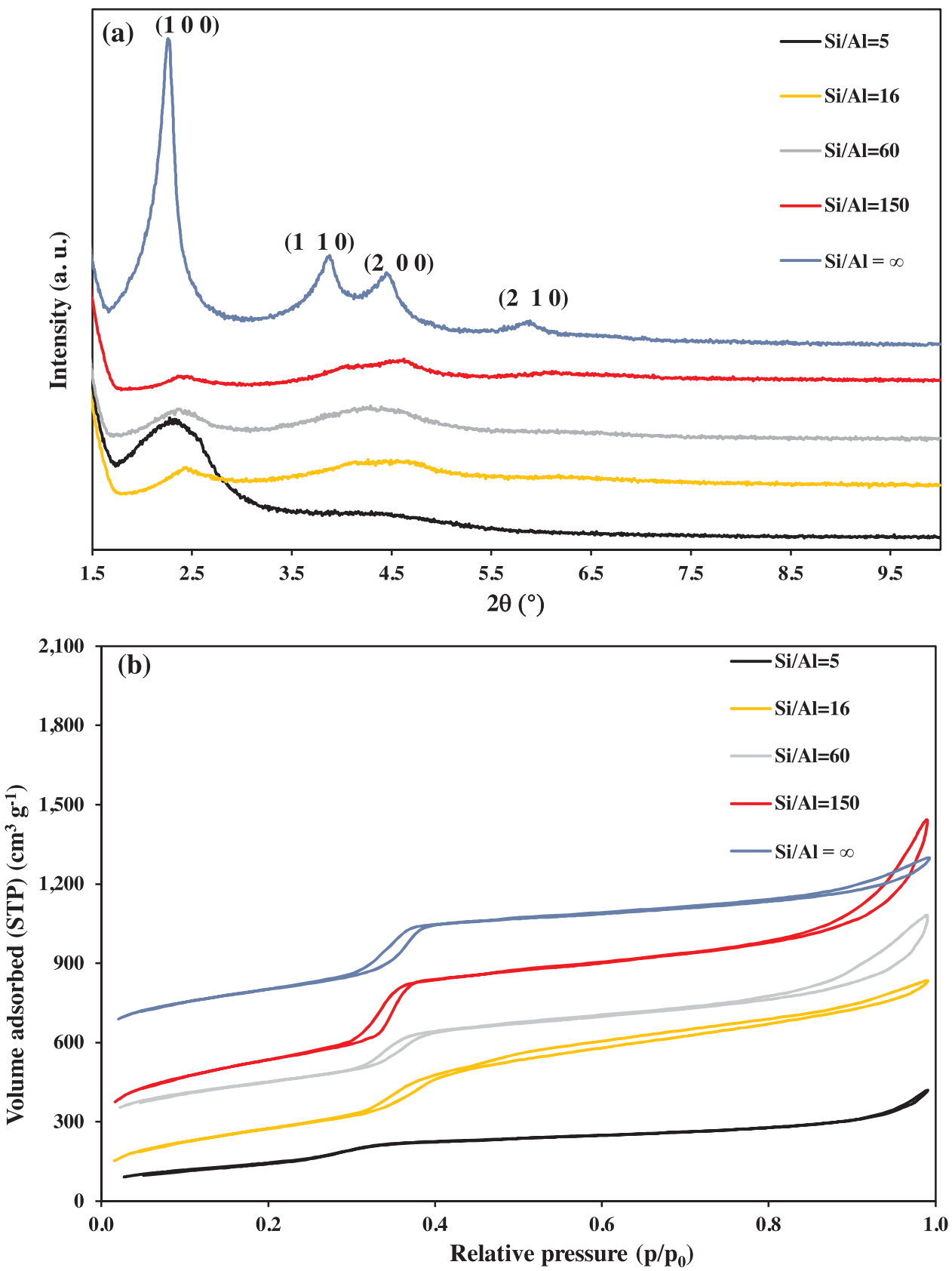

Fig. 2. (a) XRD patterns and (b) $\mathrm{N}_{2}$-physisorption isotherms of $\mathrm{Ni} / \mathrm{MCM}-41$ at different $\mathrm{Si} / \mathrm{Al}$ ratios.

Table 1

$\mathrm{N}_{2}$ physisorption results of MCM-41 at different $\mathrm{Si} / \mathrm{Al}$ ratio.

\begin{tabular}{llll}
\hline $\mathrm{Si} / \mathrm{Al}$ & $\begin{array}{l}\text { BET specific surface } \\
\left(\mathrm{m}^{2} \mathrm{~g}^{-1}\right)\end{array}$ & $\begin{array}{l}\text { Pore Volume } \\
\left(\mathrm{cm}^{3} \mathrm{~g}^{-1}\right)\end{array}$ & $\begin{array}{l}\text { Pore diameter } \mathrm{BJH}{ }^{2}, \\
(\mathrm{~nm})\end{array}$ \\
\hline 5 & 554 & 1.77 & 3.0 \\
16 & 951 & 2.31 & 3.0 \\
60 & 1095 & 1.65 & 3.0 \\
150 & 1158 & 1.72 & 3.0 \\
$\infty$ & 930 & 0.55 & 3.0 \\
\hline
\end{tabular}

${ }^{1}$ Pore volume at $\mathrm{p} / \mathrm{p}_{0}=0.99$.

${ }^{2}$ Pore diameter determined by Barret-Joyner-Halenda method (BJH) from the desorption branch.
Table 2

$\mathrm{N}_{2}$ physisorption results of $\mathrm{Ni} / \mathrm{MCM}-41$ at different $\mathrm{Si} / \mathrm{Al}$ ratio.

\begin{tabular}{llll}
\hline $\mathrm{Si} / \mathrm{Al}$ & $\begin{array}{l}\text { BET specific surface } \\
\left(\mathrm{m}^{2} \mathrm{~g}^{-1}\right)\end{array}$ & $\begin{array}{l}\text { Pore Volume } \\
\left(\mathrm{cm}^{3} \mathrm{~g}^{-1}\right)\end{array}$ & $\begin{array}{l}\text { Pore diameter BJH } \\
(\mathrm{nm})\end{array}$ \\
\hline 5 & 533 & 0.6 & 3.0 \\
16 & 928 & 1.3 & 3.0 \\
60 & 919 & 1.4 & 3.0 \\
150 & 1385 & 2.0 & 3.0 \\
$\infty$ & 1087 & 1.2 & 3.0 \\
\hline
\end{tabular}

${ }^{1}$ Pore volume at $\mathrm{p} / \mathrm{p}_{0}=0.99$.

${ }^{2}$ Pore diameter determined by Barret-Joyner-Halenda method (BJH) from the desorption branch. 

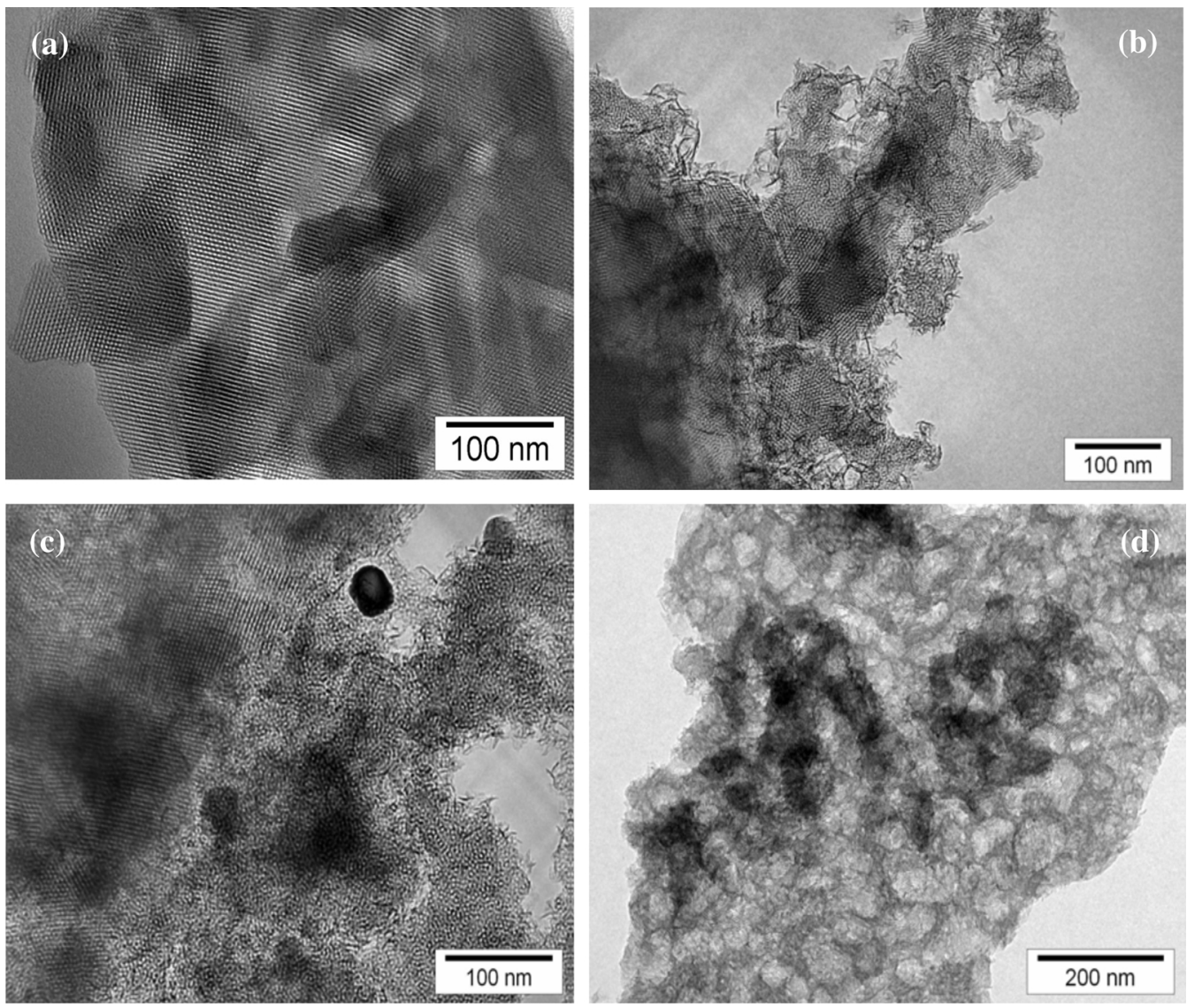

Fig. 3. TEM micrographs of (a) MCM-41, (b) Ni/MCM-41, (c) Ni/AlMCM-41 ( $\mathrm{Si} / \mathrm{Al}=150)$ and (d) Ni/AlMCM-41 (Si/Al = 16).

of the Ni containing samples, it was observed the presence of a mixture of MCM-41 structure and Ni films. For the case of the sample with a Si/ $\mathrm{Al}$ ratio of 150 it was also observed Ni particles. These particles were not observed for the case of the sample with a $\mathrm{Si} / \mathrm{Al}$ ratio of 16 . The $\mathrm{Ni}$ films are covering the structure of the MCM-41. Also, Al particles could not be observed on the surface of the adsorbents [29]. Based on the last characterization results, it is possible to conclude that the whole set of materials revealed similar structural properties to the MCM-41 materials. Therefore, the differences observed in the adsorption experiments should not be only related to the structure of the MCM-41 and Ni/MCM41 , but also, the surface acidity plays an important role.

\subsubsection{Temperature programmed desorption of Ammonia $\left(\mathrm{NH}_{3}-\mathrm{TPD}\right)$ analysis}

Considering the nitrogen physisorption, Fig. 4 illustrates the $\mathrm{NH}_{3}$ TPD profiles normalized with the BET surface of the MCM-41 samples with different $\mathrm{Si} / \mathrm{Al}$ ratio. As it has been reported in the open literature, MCM-41 is slightly acidic, but the $\mathrm{Al}$ incorporation increases strength and the number of acid sites [37-40]. The intensity of TPD profiles shows the total acidity of the adsorbents (Brönsted and Lewis acid sites). In Fig. 4, it can be observed that the surface density of the total acidity depends strongly on the $\mathrm{Si} / \mathrm{Al}$ ratio. As can be observed, the sample without $\mathrm{Al}(\mathrm{SiAl}=\infty)$ revealed a very low $\mathrm{NH}_{3}$ adsorption and just a very broad desorption of low-intensity spectrum could be observed. That means this sample presented the lowest acidity of all samples. The acidity of the rest of the samples increased considerably with the incorporation of $\mathrm{Al}$ and two broad desorption spectra could be recognized. The region of the spectra at low desorption temperature is associated with $\mathrm{NH}_{3}$ desorption from weak Brönsted and Lewis acid sites and the $\mathrm{NH}_{3}$ desorption at high temperature is associated with the presence of Brönsted and Lewis acid sites of medium strength [39,40]. It is also possible to recognize that the samples with a $\mathrm{Si} / \mathrm{Al}$ ratio of 5 and 16 revealed the presence of the highest surface density of weak acid sites. The presence of this acidity might be due because of the higher amount of $\mathrm{Al}$ in these samples and because the difficulty of incorporating $\mathrm{Al}$ into the walls of the MCM-41, as it has been previously reported for the MCM-41 containing Ni at different Si/Al ratio [29]. These materials revealed a high surface acidity for two reasons: i) the $\mathrm{Al}$ incorporation and ii) the $\mathrm{Ni}$ incorporation [41]. On these last materials, the highest amount of Brönsted and Lewis acid sites was observed on $\mathrm{Ni} / \mathrm{MCM}-41$ increasing in the following order $\mathrm{Si} / \mathrm{Al}$ ratio like: $\infty<150<60<16<5$.

\subsection{4. ${ }^{29} \mathrm{Si}$ and ${ }^{27} \mathrm{Al}$ Nuclear Magnetic Resonance (NMR) analysis}

To investigate the $\mathrm{Al}$ incorporation into the walls of the MCM-41 materials, ${ }^{29} \mathrm{Si}$ CP-MAS NMR (Fig. 5a) and ${ }^{27} \mathrm{Al}$ MAS NMR (Fig. 5b) were carried out. In the first instance, the ${ }^{29} \mathrm{Si}$ CP-MAS NMR of the samples without Ni will be interpreted (Fig. 5a). For the case of the sample MCM-41, a very broad peak of very high intensity can be observed. This peak is centered at chemical shift of $-100 \mathrm{ppm}$, which assigned to $\mathrm{Q}^{3}$ units corresponding to a layer condensation of $\mathrm{SiO}_{4}$ tetrahedral units. Around $-93 \mathrm{ppm}$ a shoulder of lower intensity could be recognized; this peak can be assigned to $\mathrm{Q}^{2}$ units. Finally, there is an important contribution of $\mathrm{Q}^{4}$ units observed at a chemical shift of around $-118 \mathrm{ppm}$ [42]. For the case of the Al MCM-41 containing samples, the intensity of all peaks was too much smaller than the corresponding samples with $\mathrm{Ni}$ [29]. All peaks are centered at $-100 \mathrm{ppm}$, this peak is associated to the presence of structural unit's $\mathrm{Si}(\mathrm{OSi})_{3}(\mathrm{OAl})$ in three-dimensionally connected aluminosilicate-like thermal-treated structures where $\mathrm{Al}$ is tetrahedral coordinated [43]. This broad peak might also be composed by $\mathrm{Si}(\mathrm{OSi})_{3} \mathrm{OH}$ units with also a very small contribution of $\mathrm{Si}(\mathrm{OSi})_{2}(\mathrm{OAl}) \mathrm{OH}$ units [43]. The low intensity of the peaks for these samples might be due to the lack of ordering of the MCM-41 walls [43]. The intensity of these peaks is quite different from 


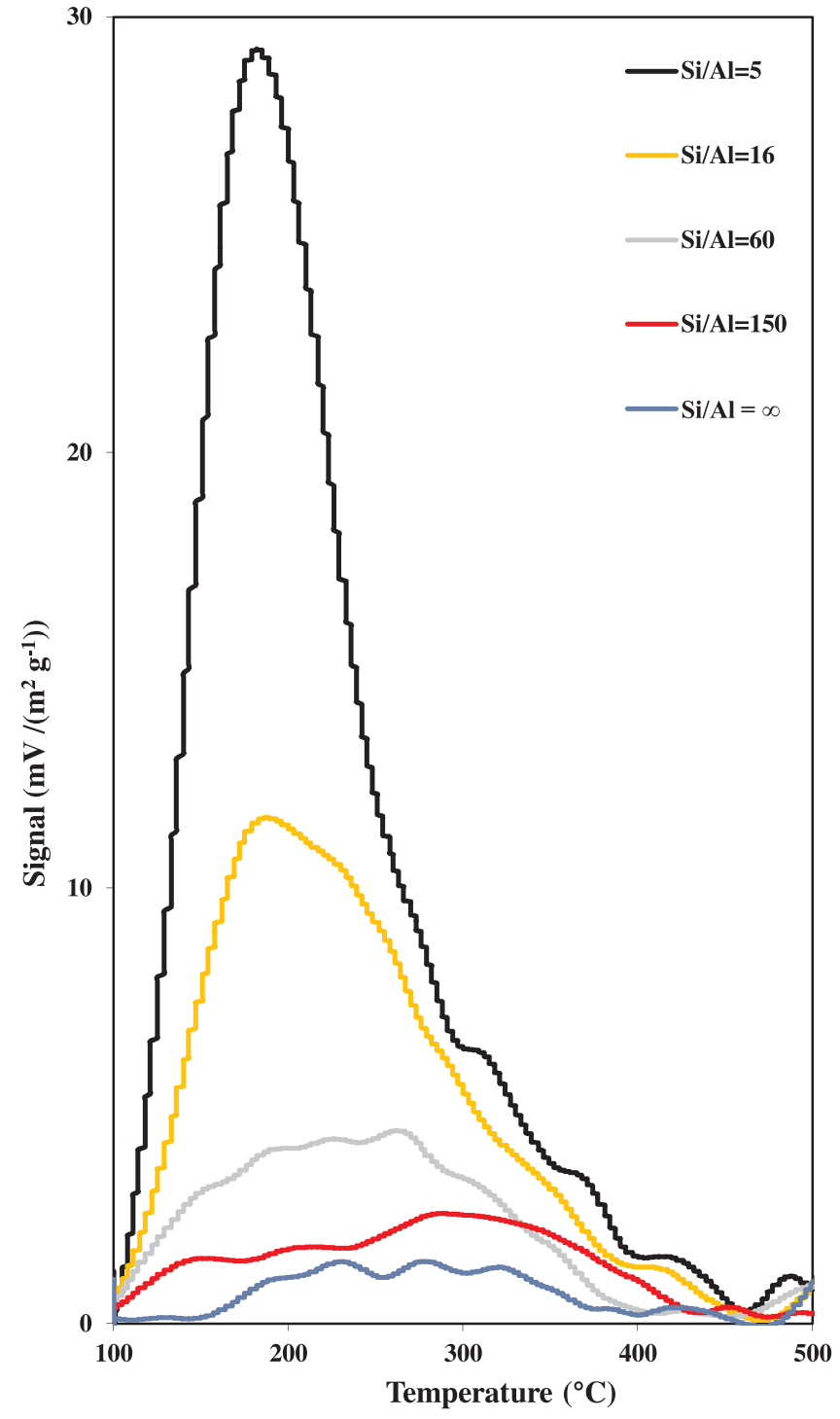

Fig. 4. $\mathrm{NH}_{3}$-TPD profiles of MCM-41 and AlMCM-41 as a function of the Si/Al ratio.

the samples containing Ni [29]. This strongly suggests that the Template Ion Exchange (TIE) improves considerably the degree of ordering the species present in the wall of the MCM-41. However, the species should be the same type in both samples. The $\mathrm{Al}$ incorporation into the MCM-41 walls was also investigated by ${ }^{27} \mathrm{Al}$ MAS NMR. From the Fig. $5 \mathrm{~b}$ can be clearly seen that the incorporation of $\mathrm{Al}$ into the wall of the MCM-41 was quite successful for the case of the samples with a $\mathrm{Si}$ / $\mathrm{Al}$ ratio of 16, 60 and 150 (tetrahedral $\mathrm{Al}$ ) because the adsorbents presented the higher acidity. This is concluded because the peak is mainly centered at $50 \mathrm{ppm}$ [43]. For the sample with the highest $\mathrm{Al}$ content $(\mathrm{Si} / \mathrm{Al}=5)$ a very broad peak of high intensity can be recognized. This peak contains significant contributions of $\mathrm{Al}$ octahedral and $\mathrm{Al}$ pentahedral, according to the results reported [39,40]. The high intensity of the peak centered at $50 \mathrm{ppm}$ might also be due to Al tetrahedral as extra-framework forming a condensate phase that has been reported in the literature for samples with low Si/Al ratio [44]. This condensate phase might trigger an essential modification of the nitrogen physisorption data because blocking of the pores (see Table 1). For the case of the Ni containing samples, very similar results have been obtained and published previously [29]. The most important difference is related to the intensity of the peaks. This might be due because of the TIE treatment for the incorporation of $\mathrm{Ni}$, where it seems that promotes the improvement of the MCM-41 structure, this part will be considered as a further study.

Based on the characterization results, it was observed a significant difference in structure and acidic properties considering the varying of $\mathrm{Si} / \mathrm{Al}$ ratio. Both aspects must be considered to explain the differences observed in the adsorption experiments with both sorbents.

\subsection{Adsorption on MCM-41 and Ni/MCM-41 considering $N$ and $S$ compounds}

Adsorptive denitrogenation and desulfurization of model fuel containing concentration of sulfur considering the DBT and nitrogen considering the $\mathrm{Q}$, with $\mathrm{N}: \mathrm{S}=1$ ratio, in dodecane as solvent at different initial concentrations $(50-250 \mathrm{ppmw})$ over two adsorbents: MCM-41 (Fig. 6) and Ni/MCM-41 (Fig. 7) with Q in presence of DBT and varying the $\mathrm{Si} / \mathrm{Al}$ ratio, are shown. The adsorption capacity of $\mathrm{N}$ when MCM-41 was used as an adsorbent in the presence of $\mathrm{S}$ at a low concentration of $\mathrm{N}$ like a $50-150 \mathrm{ppm}$ and $\mathrm{Si} / \mathrm{Al}=\infty$ ratio was highest, moreover, when using $\mathrm{Si} / \mathrm{Al}=5$ ratio has the lowest nitrogen adsorption are presented in Fig. 6a. The maximum adsorption of nitrogen was obtained by using the $\mathrm{Si} / \mathrm{Al}=\infty$ ratio because it presented a large surface area compared to the $\mathrm{Si} / \mathrm{Al}$ ratio $=5$ (see Table 1 ), although its ratio presented the lowest acidity. When increasing the initial nitrogen concentration content, the adsorption capacities decreased, this may due to the saturation of adsorbent. Additionally, sulfur removal is shown in Fig. 6b. Using MCM-41 with $\mathrm{Si} / \mathrm{Al}=\infty$ ratio was much lower than nitrogen removal approximately 10 times smaller (between 1-10\% of removal). The main difference was that at $\mathrm{Si} / \mathrm{Al}=5$ ratio present the highest value at $50 \mathrm{ppmw}$ of $\mathrm{S}$ and when increase the sulfur content, at high value ratio presented almost the same value although we have a smaller specific surface, by the results of $\mathrm{NH}_{3}$-TPD and NMR analysis showed in characterization results (Section 3.1.3), we have more Lewis acid sites with this material and the DBT should be adsorbed in this sites, according to with Liao et al. [13] and Subhan and Liu [21]. Besides, when using $\mathrm{Si} / \mathrm{Al}=150$ and $\infty$ ratio for all content of $\mathrm{S}$ presented the lowest values of removal between 1 and $3 \%$, this should be by diminishing of sites acid presumably Lewis.

On the other hand, the adsorption measurements of nitrogen removal as $\mathrm{Q}$ in the presence of sulfur as DBT in the model diesel fuel considering the Ni/MCM-41 as adsorbent and varying the $\mathrm{Si} / \mathrm{Al}$ ratio are shown in Fig. 7. When using MCM-41 as adsorbent the behavior was very similar than $\mathrm{Ni} / \mathrm{MCM}-41$ for removal of $\mathrm{N}$ using $\mathrm{Si} / \mathrm{Al}=\infty$ ratio, however, for the other ratios it decreased between 10 and $25 \%$, it is because present almost the same specific surface, $S_{\mathrm{BET}}=930 \mathrm{~m}^{2} \mathrm{~g}^{-1}$ with MCM-41 (Table 1 ) and with Ni/MCM-41 using Si/Al $=\infty$ ratio the $\mathrm{S}_{\mathrm{BET}}=1087 \mathrm{~m}^{2} \mathrm{~g}^{-1}$ (Table 2), just as the pore size presented same values, therefore the adsorption process is not influenced by this parameter. [29]. Besides, when considering sulfur, as illustrated in Fig. $7 \mathrm{~b}$, we can see that at low sulfur content the removal decreased. However, at high sulfur contents presented highest removal at $\mathrm{Si}$ / $\mathrm{Al}=5$, it may be due to higher acidity in this material and that DBT is being adsorbed on Ni particles, this is important, because the petroleum had higher content of sulfur, also reported by García-Martínez et al. [31]. It should be noted that at high concentrations of nitrogen, the adsorption was lower and that of sulfur was higher; this may be a problem because there is a higher specific surface, pore diameter and pore volume available to adsorb the DBT (Table 1 and Table 2).

Thus far, the discussion of the results has been focused on the adsorption of nitrogen because it seems that the mesoporous materials used are capable of adsorbing selectively $\mathrm{Q}$ from a mixture of nitrogen and sulfur compounds on MCM-41 and $\mathrm{Si} / \mathrm{Al}=\infty$, and the adsorption capacity is much higher than that of DBT. Therefore, the selective adsorption of nitrogen in the presence of sulfur compounds becomes relevant to this kind of adsorbent. The high specific surface and wide pore diameter of MCM-41 is one of the main factors in the adsorption of this basic molecule. On the other hand, with $\mathrm{Ni} / \mathrm{MCM}-41$ at a low $\mathrm{Si} / \mathrm{Al}$ 

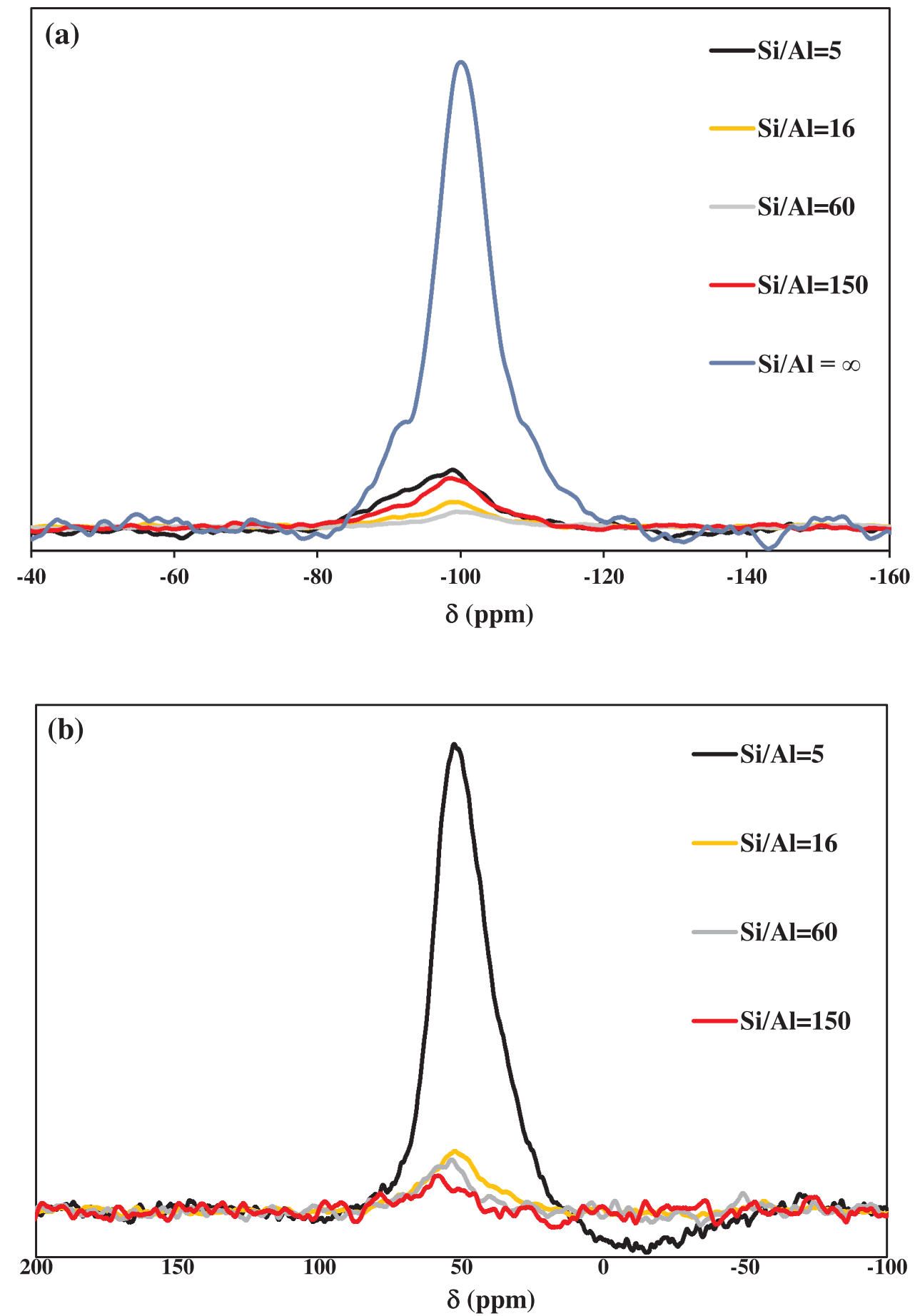

Fig. 5. (a) ${ }^{29}$ Si CP-MAS NMR spectra and (b) ${ }^{27}$ Al MAS NMR spectra indirect detection with MCM-41 at different Si/Al ratio.

ratio, the hypothesis that we have is the possibility that acid Lewis sites are available on the surface of the mesoporous material at these temperatures will function to adsorb the sulfur compound.

\subsection{Adsorption kinetics}

In this section shows the kinetic results, since the correlation coefficients were closed to the unity in the same way that other works $[27,28,31]$, the parameters calculated from kinetic models are summarized in Table 3, the adsorption behavior of $\mathrm{Q}$ can be described appropriately by the pseudo-second-order kinetic in the same way that a lot of works $[7,16,17,22,27,28,31,45]$. Adsorption kinetics determine the adsorbate uptake rate of nitrogen and sulfur compounds. The adsorption kinetics of $\mathrm{Q}$ at different concentrations, expressed in parts per million weight of $\mathrm{N}$ in the presence of sulfur with DBT in model diesel fuel, are shown. The adsorption constant was adjusted with the linearized equation of the model (Eq. 4), considering the experimental data of the concentration of nitrogen in the form of Q. In Table 3, one may also note that the theoretical adsorption capacity expressed by the kinetic constant of adsorption ( $\mathrm{k}_{\mathrm{ads}}$ ) and MCM-41 as adsorbent at the initial concentration of $50 \mathrm{ppmw}$ of $\mathrm{N}$ presented the highest value of $25.7 \mathrm{~g} \mathrm{mmol}^{-1} \mathrm{~min}^{-1}$ with $\mathrm{Si} / \mathrm{Al}=60$ ratios followed by $\mathrm{Si} / \mathrm{Al}=16$ and decreased when nitrogen content was increased $(22-67 \%$ at 100 ppmw) but when increasing the nitrogen content at $150 \mathrm{ppmw}$ 

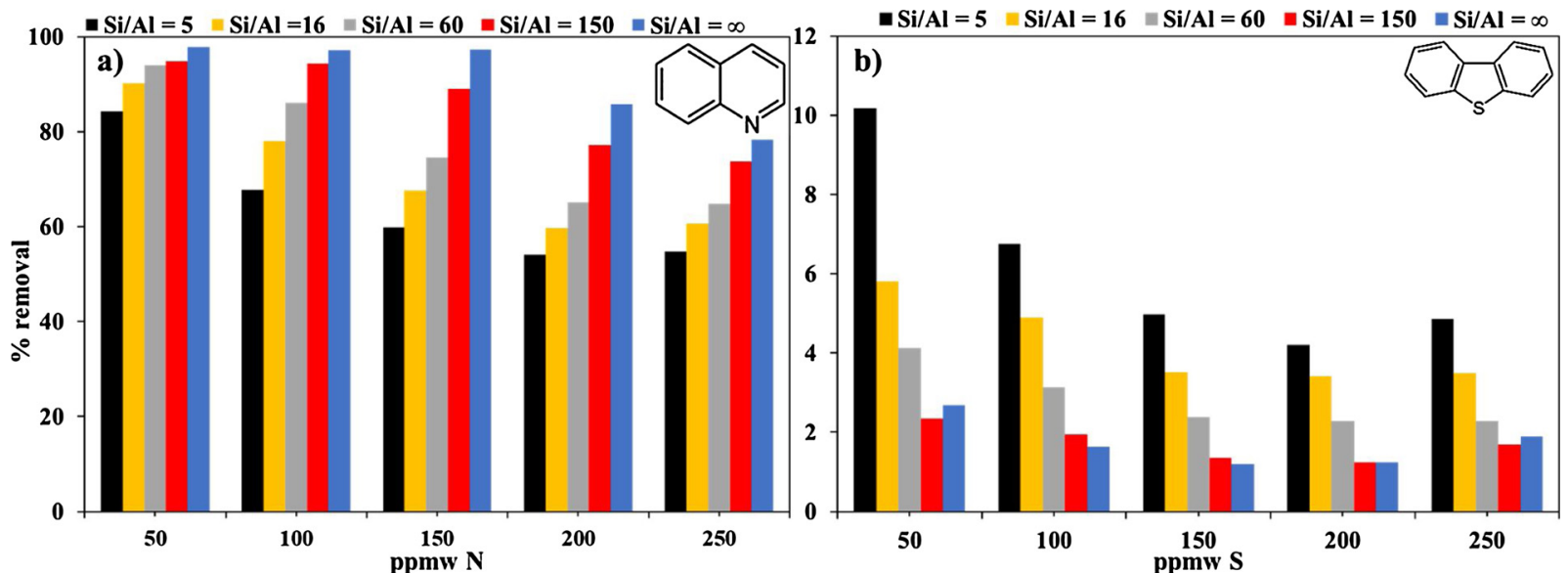

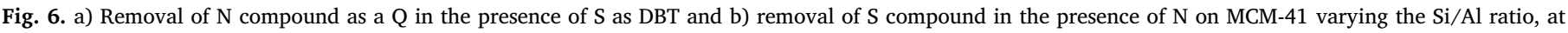
different initial concentrations with a N:S $=1$ ratio at $313 \mathrm{~K}$.
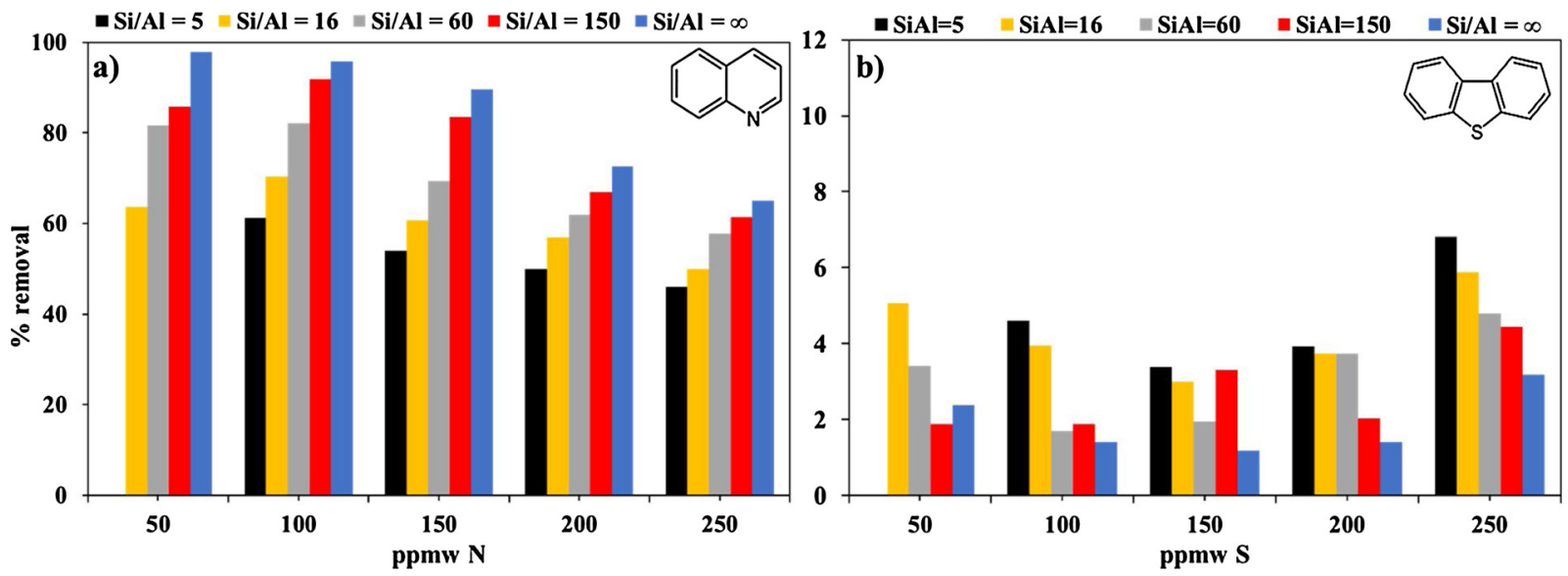

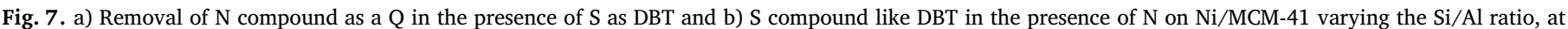
different initial concentrations with a N:S $=1$ ratio at $313 \mathrm{~K}$.

Table 3

Adsorption constants with MCM-41 and Ni/MCM-41 varying the $\mathrm{Si} / \mathrm{Al}$ ratio at different concentrations of $\mathrm{N}$ and $\mathrm{N} / \mathrm{S}=1$ ratio.

\begin{tabular}{|c|c|c|c|c|c|c|c|c|c|c|}
\hline \multirow[b]{3}{*}{ Ratio $\mathrm{Si} / \mathrm{Al}$} & \multicolumn{5}{|c|}{ MCM-41 ppm N } & \multicolumn{5}{|c|}{ Ni/MCM-41 ppm N } \\
\hline & \multicolumn{5}{|c|}{$\mathrm{k}_{\text {ads }}\left[\mathrm{g} \mathrm{mmol}^{-1} \min ^{-1}\right]$} & \multicolumn{5}{|c|}{$\mathrm{k}_{\text {ads }}\left[\mathrm{g} \mathrm{mmol}^{-1} \min ^{-1}\right]$} \\
\hline & 50 & 100 & 150 & 200 & 250 & 50 & 100 & 150 & 200 & 250 \\
\hline 5 & 2.8 & 2.2 & 2.6 & 2.3 & 3.5 & 1.5 & 3.7 & 1.8 & 1.8 & 5.9 \\
\hline 16 & 9.8 & 2.9 & 2.8 & 2.3 & 1.9 & 1.9 & 2.7 & 11.5 & 13.4 & 92.5 \\
\hline 60 & 25.7 & 11.8 & 4.7 & 7.2 & 17.7 & 3.4 & 4.5 & 2.4 & 3.3 & 2.4 \\
\hline 150 & 8.0 & 4.4 & 3.1 & 5.2 & 2.6 & 3.6 & 11.8 & 2.0 & 2.2 & 3.2 \\
\hline$\infty$ & 3.4 & 1.9 & 4.2 & 9.3 & 9.8 & 3.1 & 10.6 & 5.3 & 36.1 & 0.9 \\
\hline
\end{tabular}

almost all remained constant, presenting an increase in the $\mathrm{Si} / \mathrm{Al}=60$ and $\infty$, this may be due to the increase in surface area (Table 1 ). Moreover, when using the Ni/MCM-41, these values decreased than MCM-41 as adsorbent, but when using the $\mathrm{Si} / \mathrm{Al}=16$ at 250 ppmw of $\mathrm{N}$ this value $\left(92.5 \mathrm{~g} \mathrm{mmol}^{-1} \mathrm{~min}^{-1}\right)$ was higher than other values.

\subsection{Isotherm adsorption using $M C M-41$ and $N i / M C M-41$ with nitrogen using $Q$}

These materials were used to remove $\mathrm{Q}$ and DBT molecules from model diesel fuel. In these experiments, it was shown that removal of nitrogen and sulfur atom were fitted to the corresponding isotherm, Langmuir or Freundlich models, and removal in the presence of both compounds at $\mathrm{N}: \mathrm{S}=1$ ratio.
In Fig. 8 we can see the equilibrium adsorption against concentration at equilibrium results of nitrogen using $\mathrm{Q}$ with all ratio of $\mathrm{Si} / \mathrm{Al}$ used in this work and both adsorbents: MCM-41: Fig. 8a and Ni/MCM41: Fig. 8b, in both materials were higher values than reported by Silva et al. [46] that presented $\mathrm{q}_{\mathrm{e}}=1.0 \mathrm{mmol} \mathrm{g}_{\text {ads }}{ }^{-1}$ with Silica-Alumina as adsorbent. The dotted lines show the adjustment of the isotherm to the experimental data; this adjustment was using the Langmuir isotherm for $\mathrm{Si} / \mathrm{Al}=150$ and $\infty$ ratio and Freundlich isotherm for $\mathrm{Si} / \mathrm{Al}=5,15$ and 60 ratios with MCM-41 as adsorbent (Fig. 8a), presenting values higher (129-259 mg/g) than Ahmed et al. [47] between $110-170 \mathrm{mg} / \mathrm{g}$. We can observe that the best fitting considering at $\mathrm{Si} / \mathrm{Al}=150$ and $\infty$ ratio was when considering the Langmuir model, in the same way that Arcibar-Orozco et al. [48]. Thus, assume that $\mathrm{Q}$ adsorbs formation of a few adsorption layers, and it can be seen that the highest nitrogen 

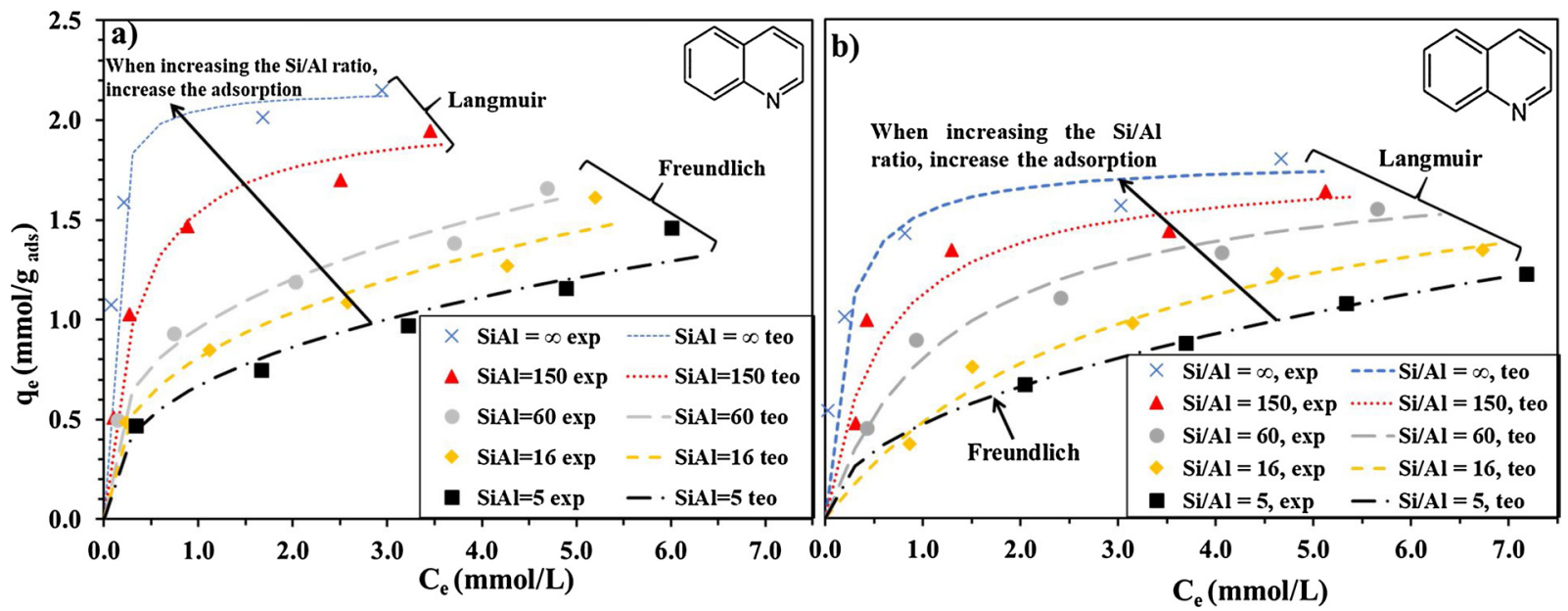

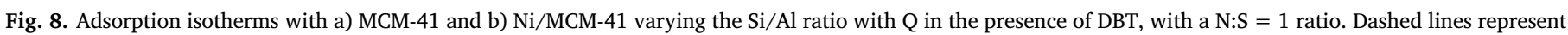
Langmuir or Freundlich model.

adsorption was found at $\mathrm{Si} / \mathrm{Al}=\infty$ followed by 150 ratio. Besides, these should be by higher specific surface values with high $\mathrm{Si} / \mathrm{Al}$ ratio (Table 1), moreover, with $\mathrm{Si} / \mathrm{Al}=5,15$ and 60 ratio the Freundlich model was adjusted at experimental data, this means that we have heterogeneous surface non-ideal and reversible adsorption, not restricted to the formation of monolayer. This empirical model can be applied to multilayer adsorption, with non-uniform distribution of adsorption heat and affinities over the heterogeneous surface [49]. For example, Chang Hyun et al. [50] used different materials in the adsorption of sulfur, these authors employed a beta zeolite (BEA), MCM41 and SBA-15 with Ag as active phase, meanwhile the MCM-41 presented the higher surface area, no presented the better results in adsorption [50], but in the present work interesting results were found for the adsorption of both molecules. Furthermore, when using the $\mathrm{Ni}$ / MCM-41 as adsorbent (Fig. 8b) the maximum adsorption in Langmuir isotherm was lower than MCM-41 for almost all Si/Al ratio (30 \% approximately), because this empirical model assumes monolayer adsorption (the adsorbed layer is one molecule in thickness), with adsorption can only occur at a finite (fixed) number of definite localized sites, that are identical and equivalent, with no lateral interaction and steric hindrance between the adsorbed molecules, even on adjacent sites [51], except at $\mathrm{Si} / \mathrm{Al}=5$ ratio, moreover the equilibrium concentration was higher with Ni/MCM-41 as adsorbent than MCM-41, shown in Fig. 8b.

Besides, in Table 4 are presented the values obtained from the constants for the theoretical model parameters using Langmuir and Freundlich isotherm and correlation factor that was adjusted considering the nitrogen adsorption with material MCM-41 and Ni/MCM41 at $\mathrm{N}: \mathrm{S}=1$ ratio. Considering MCM-41 as adsorbent (Table $4 \mathrm{a}$ ) it is observed that the best model that fit high values of the correlation factor was that considering Langmuir $(\mathrm{Si} / \mathrm{Al}=150$ and $\infty)$, while the Freundlich model adjusted to small values of the $\mathrm{Si} / \mathrm{Al}=5,16$ and 60 ratios (Table 4b), this confirms what was found that there was a lower adsorption of the $\mathrm{Q}$. We can see that at a low $\mathrm{Si} / \mathrm{Al}$ ratio, the value of $\mathrm{q}_{\mathrm{m}}$ showed the lowest values (between $1.65-1.75 \mathrm{mmol} / \mathrm{g}$ ) and $\mathrm{K}_{\mathrm{L}}$ presented values smaller than unity $(0.63-1.57 \mathrm{~L} / \mathrm{mmol})$ between $\mathrm{Si}$ / $\mathrm{Al}=5-60$. However, when increasing the $\mathrm{Si} / \mathrm{Al}$ ratio, the value of $\mathrm{q}_{\mathrm{m}}$ and the constant of Langmuir $\mathrm{K}_{\mathrm{L}}$ showed the values of $2.16 \mathrm{mmol} / \mathrm{g}$ and $19.09 \mathrm{~L} / \mathrm{mmol}$, respectively, at $\mathrm{Si} / \mathrm{Al}=\infty$ and the values of the other ratios were lower, these values are higher than reported by ArcibarOrozco et al. [48] using carbon as adsorbent and $\mathrm{Fe}-\mathrm{Mn}\left(\mathrm{q}_{\mathrm{m}}=0.546\right.$ $0.756 \mathrm{mmol} / \mathrm{g}$ and $\mathrm{K}_{\mathrm{L}}=0.99-1.44 \mathrm{mmol} / \mathrm{g}$ ). This helps us to confirm that $\mathrm{Q}$ is being adsorbed preferentially at high $\mathrm{Si} / \mathrm{Al}$ ratio, it is worth mentioning that the correlation factor for low values of the $\mathrm{Si} / \mathrm{Al}(5,16$ and 60 ) ratios were lesser than 0.98 , moreover, with $\mathrm{Si} / \mathrm{Al}(5,16$ and 60 ) ratios using the Freundlich isotherm the $1 / n$ values were smaller

Table 4

Theoretical model parameters for the adsorption of $\mathrm{Q}$ compounds varying the Si/Al ratio using both adsorbents: MCM-41 and Ni/MCM-41, a) Langmuir and b) Freundlich.

\begin{tabular}{|c|c|c|c|c|c|c|c|c|}
\hline \multirow{2}{*}{$\begin{array}{l}\text { a) } \\
\text { Ratio } \mathrm{Si} / \mathrm{Al}\end{array}$} & \multicolumn{4}{|c|}{ MCM-41 Langmuir } & \multicolumn{4}{|c|}{ Ni/MCM-41 Langmuir } \\
\hline & $\mathrm{q}_{\mathrm{m}}(\mathrm{mmol} / \mathrm{g})$ & $\mathrm{K}_{\mathrm{L}}(\mathrm{L} / \mathrm{mmol})$ & Equation & $\mathrm{R}^{2}$ & $\mathrm{q}_{\mathrm{m}}(\mathrm{mmol} / \mathrm{g})$ & $\mathrm{K}_{\mathrm{L}}(\mathrm{L} / \mathrm{mmol})$ & Equation & $\mathrm{R}^{2}$ \\
\hline 5 & 1.65 & 0.63 & $q_{e}=\frac{1.04 C_{e}}{1+0.63 C_{e}}$ & 0.913 & 1.86 & 0.26 & $q_{e}=\frac{0.48 C_{e}}{1+0.26 C_{e}}$ & 0.991 \\
\hline 16 & 1.73 & 0.95 & $q_{e}=\frac{1.64 C_{e}}{1+0.95 C_{e}}$ & 0.938 & 2.01 & 0.31 & $q_{e}=\frac{0.62 C_{e}}{1+0.31 C_{e}}$ & 0.956 \\
\hline 60 & 1.75 & 1.57 & $q_{e}=\frac{2.75 C_{e}}{1+1.57 C_{e}}$ & 0.972 & 1.83 & 0.78 & $q_{e}=\frac{1.43 C_{e}}{1+0.78 C_{e}}$ & 0.983 \\
\hline 150 & 2.05 & 3.02 & $q_{e}=\frac{6.19 C_{e}}{1+3.02 C_{e}}$ & 0.993 & 1.78 & 1.70 & $q_{e}=\frac{3.03 C_{e}}{1+1.70 C_{e}}$ & 0.986 \\
\hline$\infty$ & 2.16 & 19.09 & $q_{e}=\frac{41.23 C_{e}}{1+19.09 C_{e}}$ & 0.998 & 1.80 & 5.37 & $q_{e}=\frac{9.66 C_{e}}{1+5.37 C_{e}}$ & 0.993 \\
\hline b) & \multicolumn{4}{|c|}{ MCM-41 Freundlich } & \multicolumn{4}{|c|}{ Ni/MCM-41 Freundlich } \\
\hline Ratio $\mathrm{Si} / \mathrm{Al}$ & $1 / \mathrm{n}$ & $\mathrm{K}_{\mathrm{F}}\left(\mathrm{L}^{1 / \mathrm{n}} \operatorname{mmol}\left({ }^{\mathrm{n}-1) / \mathrm{n}} / \mathrm{g}\right)\right.$ & Equation & $\mathrm{R}^{2}$ & $1 / \mathrm{n}$ & $\mathrm{K}_{\mathrm{F}}\left(\mathrm{L}^{1 / \mathrm{n}} \mathrm{mmol}\left({ }^{\mathrm{n}-1) / \mathrm{n}} / \mathrm{g}\right)\right.$ & Equation & $\mathrm{R}^{2}$ \\
\hline 5 & 0.37 & 0.668 & $q_{e}=0.668 C_{e}^{0.37}$ & 0.964 & 0.49 & 0.470 & $q_{e}=0.470 C_{e}^{0.487}$ & 0.998 \\
\hline 16 & 0.36 & 0.808 & $q_{e}=0.808 C_{e}^{0.36}$ & 0.980 & 0.59 & 0.481 & $q_{e}=0.481 C_{e}^{0.59}$ & 0.919 \\
\hline 60 & 0.33 & 0.959 & $q_{e}=0.959 C_{e}^{0.33}$ & 0.987 & 0.43 & 0.753 & $q_{e}=0.753 C_{e}^{0.43}$ & 0.932 \\
\hline 150 & 0.35 & 1.340 & $q_{e}=1.340 C_{e}^{0.35}$ & 0.914 & 0.35 & 0.999 & $q_{e}=0.999 C_{e}^{0.35}$ & 0.741 \\
\hline$\infty$ & 0.011 & 1.418 & $q_{e}=1.418 C_{e}^{0.011}$ & 0.101 & 0.23 & 1.319 & $q_{e}=1.319 C_{e}^{0.23}$ & 0.952 \\
\hline
\end{tabular}


than unity, this implies chemisorption's process and $\mathrm{K}_{\mathrm{F}}$ increased the values in the same way that ratio $\left(0.668-0.959 \mathrm{~L}^{1 / \mathrm{n}} \mathrm{mmol}^{(\mathrm{n}-1) / \mathrm{n}} / \mathrm{g}\right)$. Besides, the values obtained from the constants for the isotherm that was adjusted considering the $\mathrm{Q}$ adsorption, but now with material $\mathrm{Ni}$ / MCM-41 was presented in Table 4, we can see in almost all values of the $\mathrm{Si} / \mathrm{Al}$ ratio, the Langmuir model was adjusted. The Freundlich model was adjusted only with the $\mathrm{Si} / \mathrm{Al}=5$ value, showing lower adsorption of the $\mathrm{Q}$ at this ratio, this means that we have heterogeneous surface, and possibly multilayer adsorption. At almost ratio of $\mathrm{Si} / \mathrm{Al}$ the constant of Langmuir of $\mathrm{q}_{\mathrm{m}}$ presented almost the same behavior that MCM-41 adsorbent (between 1.78 and $2.01 \mathrm{mmol} / \mathrm{g}$ ), the above gives us serves to try to explain that $\mathrm{Q}$ is being adsorbed without Ni. Moreover, the constant $\mathrm{K}_{\mathrm{L}}$ presented values smaller than MCM-41 as adsorbent (between $0.26-5.37 \mathrm{~L} / \mathrm{mmol}$ ); this helps us to think that $\mathrm{Q}$ is being adsorbed preferentially and more quickly without Ni. Finally, in Table 4b shows the Freundlich parameters with MCM-41 and we can see that $1 / \mathrm{n}$ value is found between 0.011- 0.37, the Freundlich constant between $0.668-1.418$ and correlation factor nearly to the unity between 0.964 and 0.987 , considering low $\mathrm{Si} / \mathrm{Al}$ ratio $(5,16$ and 60$)$. On the other hand, with Ni/MCM-41 only the low $\mathrm{Si} / \mathrm{Al}=5$ was adjusted the correlation factor showing the following values of $1 / \mathrm{n}=0.49$ and $\mathrm{K}_{\mathrm{F}}=0.470 \mathrm{~L}^{1 / \mathrm{n}} \mathrm{mmol}^{(\mathrm{n}-1) / \mathrm{n}} / \mathrm{g}$, in the same way that MCM- 41 with $1 / \mathrm{n}$ values implies chemisorption's process.

\subsection{Isotherm adsorption with MCM-41 and Ni/MCM-41 with sulfur using} as $D B T$

The adsorption removal with both sorbents was presented in Fig. 9, considering the sulfur as DBT with both adsorbents and $\mathrm{N}: \mathrm{S}=1$ ratio with MCM-41: Fig. 9a and Ni/MCM-41: Fig. 9a. The behavior present different forms that are shown with the $\mathrm{Q}$ and MCM-41 adsorbent (Fig. 8). Since using $\mathrm{Si} / \mathrm{Al}=5$ and 16 show the highest removal for sulfur in the presence of nitrogen decreased when increasing the ratio for two adsorbents, meanwhile, with $\mathrm{Si} / \mathrm{Al}>60$, shows lower sulfur adsorption, in the same way that Subhan et al. [45]. With the total sulfur capacity increase with the decline of $\mathrm{Si} / \mathrm{Al}$ ratio and reaches to highest capacity of $12.5 \mathrm{mg} \mathrm{S} / \mathrm{g}$ ads with $\mathrm{Si} / \mathrm{Al}=15$ and DBT as precursor of $\mathrm{S}$ (518 ppmw S) with $\mathrm{Ni}$, this revealed that the high sulfur capacity of sorbent correlated closely with high Lewis acid sites according with Subhan et al. [45] in pure case was between $1.8-11.1 \mathrm{mg} /$ g. Moreover, these values are lower than reported by Arcibar-Orozco et al. [48], because the values are $\mathrm{q}_{\mathrm{m}}=0.136-0.155 \mathrm{mmol} / \mathrm{g}$.

Results to describe the adsorption processes considering DBT indicate that the Langmuir model did not adjust to experimental data showing the values of factor correlation less than unity using two adsorbents (Table $5 \mathrm{a}$ and $\mathrm{b}$ ). This is attributed to the fact that the amount of sulfur adsorbed in the adsorbent is tiny and that is why the model was not adequately adjusted to the experimental data. According to density functional theory (DFT) used by Parr and Pearson [52] and Pearson's classification, DBT is considered a soft base and the ion $\mathrm{Ni}^{2+}$ are borderlines acids. When the ion of $\mathrm{Ni}^{2+}$ is loaded on the surface of MCM-41, the local hard acid of the surface is weakened, which enhances the adsorption of DBT. Furthermore, the $\pi$-complexation on the surface of Ni/MCM-41 also plays an essential role in DBT adsorption [53]. However, Freundlich model for two adsorbents is appropriate, which suggests that multilayer adsorption takes place for the adsorption of sulfur compound with MCM-41 (Table 5b), according with GarcíaMartínez et al. [31], because they show that sulfur compound adsorb on $\mathrm{Ni}$ in Ni/MCM-41 adsorbent and involve $\pi$ complexation on acid site possibly in acid Lewis sites.

Moreover, as can be seen with two adsorbents in Fig. 9 the DBT adsorption process is heterogeneous and infinite surface coverage of the adsorbate occurred without maximum adsorption. The value in Freundlich equation with MCM-41 of $1 / \mathrm{n}$ was found to be between 0.49 and 0.66 indicating various aspects like; nonlinearity degree of adsorption, possible chemical process. Moreover, when using Ni/MCM-41 as adsorbent the value in Freundlich equation of $1 / \mathrm{n}$ was found to be nearly and higher than the unity, indicating that the adsorption is a favorable process and multilayer adsorption, this indicates that saturation was not attained. Because the DBT is relatively poorly adsorbed, that is why there is no good fit of the model to the experimental data and therefore the decrease the adjust of experimental and theoretical data. Something important to consider is that Subhan et al. [45] revealing that $\mathrm{Ni}$ incorporation in AlKIT-6(15) can generate a large amount of acid sites in the sorbents necessary to carry out the adsorption of sulfur as DBT. Therefore, it can propose that the adsorption on DBT preferentially occurs on Ni in flat positions in the same way that García-Martínez et al. [31] and Colín-Luna et al. [54] and as discussed previously.

Moreover, the selectivity was calculated considering the Eq. (2), and the results were shown in Table 6 with both adsorbents: MCM-41 and $\mathrm{Ni} / \mathrm{MCM}-41$. We can see that using the MCM-41 as adsorbent; we can see that low content of $\mathrm{N}$ and $\mathrm{Si} / \mathrm{Al}=\infty$ shows the highest of selectivity value than the other concentrations of $\mathrm{N}$ and $\mathrm{Si} / \mathrm{Al}$ ratio. Likewise, with Ni/MCM-41 as adsorbent the selectivity was lower than MCM-41, this means that MCM-41 presents more selectivity for eliminating the $\mathrm{Q}$ than $\mathrm{Ni} / \mathrm{MCM}-41$, but this lastly adsorbent is more selective for DBT adsorption.

\section{Conclusions}

Considering the characterization results, we observed that a higher

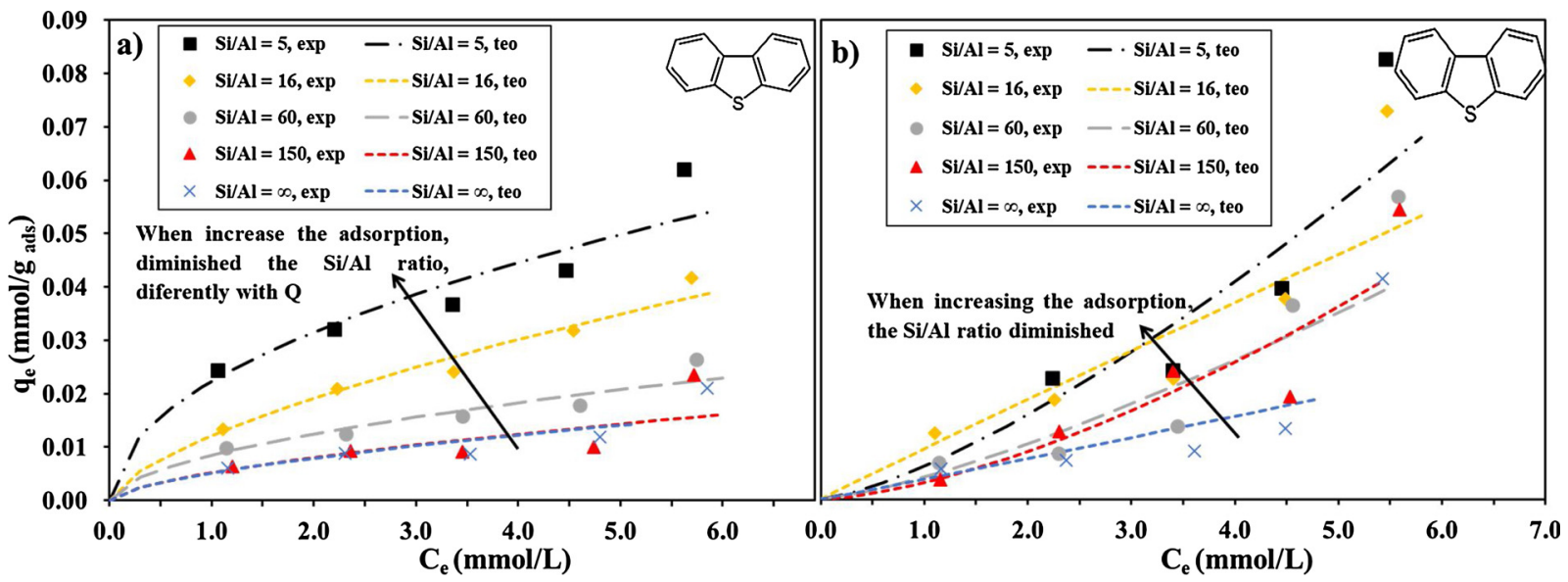

Fig. 9. Adsorption isotherms with a) MCM-41 and b) Ni/MCM-41varying the Si/Al ratio with DBT in the presence of $\mathrm{Q}$ with a ratio N:S = 1. Dashed lines represent the Freundlich model. 
Table 5

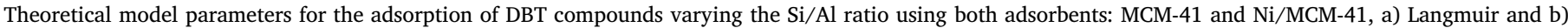
Freundlich.

\begin{tabular}{|c|c|c|c|c|c|c|c|c|}
\hline \multirow{2}{*}{$\begin{array}{l}\text { a) } \\
\text { Ratio } \mathrm{Si} / \mathrm{Al}\end{array}$} & \multicolumn{4}{|c|}{ MCM-41 Langmuir } & \multicolumn{4}{|c|}{ Ni/MCM-41 Langmuir } \\
\hline & $\mathrm{q}_{\mathrm{m}}(\mathrm{mmol} / \mathrm{g})$ & $\mathrm{K}_{\mathrm{L}}(\mathrm{L} / \mathrm{mmol})$ & Equation & $\mathrm{R}^{2}$ & $\mathrm{q}_{\mathrm{m}}(\mathrm{mmol} / \mathrm{g})$ & $\mathrm{K}_{\mathrm{L}}(\mathrm{L} / \mathrm{mmol})$ & Equation & $\mathrm{R}^{2}$ \\
\hline 5 & 0.088 & 0.27 & $q_{e}=\frac{0.024 C_{e}}{1+0.273 C_{e}}$ & 0.739 & -0.090 & -0.075 & $q_{e}=\frac{0.0068 C_{e}}{1-0.075 C_{e}}$ & 0.245 \\
\hline 16 & 0.081 & 0.15 & $q_{e}=\frac{0.012 C_{e}}{1+0.15 C_{e}}$ & 0.747 & -0.494 & -0.017 & $q_{e}=\frac{0.0085 C_{e}}{1-0.017 C_{e}}$ & 0.014 \\
\hline 60 & 0.042 & 0.21 & $q_{e}=\frac{0.009 C_{e}}{1+0.21 C_{e}}$ & 0.672 & -0.042 & -0.092 & $q_{e}=\frac{0.0038 C_{e}}{1-0.092 C_{e}}$ & 0.320 \\
\hline 150 & 0.036 & 0.14 & $q_{e}=\frac{0.005 C_{e}}{1+0.14 C_{e}}$ & 0.220 & -0.030 & -0.108 & $q_{e}=\frac{0.0032 C_{e}}{1-0.108 C_{e}}$ & 0.496 \\
\hline$\infty$ & 0.036 & 0.135 & $q_{e}=\frac{0.005 C_{e}}{1+19.09 C_{e}}$ & 0.302 & -0.124 & -0.026 & $q_{e}=\frac{0.0033 C_{e}}{1-0.026 C_{e}}$ & 0.016 \\
\hline b) & \multicolumn{4}{|c|}{ MCM-41 Freundlich } & \multicolumn{4}{|c|}{ Ni/MCM-41 Freundlich } \\
\hline Ratio $\mathrm{Si} / \mathrm{Al}$ & $1 / \mathrm{n}$ & $\mathrm{K}_{\mathrm{F}}\left(\mathrm{L}^{1 / \mathrm{n}} \mathrm{mmol}\left({ }^{\mathrm{n}-1) / \mathrm{n}} / \mathrm{g}\right)\right.$ & Equation & $\mathrm{R}^{2}$ & $1 / \mathrm{n}$ & $\mathrm{K}_{\mathrm{F}}\left(\mathrm{L}^{1 / \mathrm{n}} \mathrm{mmol}\left({ }^{\mathrm{n}-1) / \mathrm{n}} / \mathrm{g}\right)\right.$ & Equation & $\mathrm{R}^{2}$ \\
\hline 5 & 0.49 & 0.022 & $q_{e}=0.022 C_{e}^{0.49}$ & 0.898 & 1.33 & 0.0062 & $q_{e}=0.0062 C_{e}^{1.33}$ & 0.772 \\
\hline 16 & 0.66 & 0.0121 & $q_{e}=0.0121 C_{e}^{0.66}$ & 0.969 & 0.98 & 0.0095 & $q_{e}=0.0095 C_{e}^{0.98}$ & 0.837 \\
\hline 60 & 0.56 & 0.0084 & $q_{e}=0.0084 C_{e}^{0.56}$ & 0.932 & 1.32 & 0.0042 & $q_{e}=0.0042 C_{e}^{1.32}$ & 0.824 \\
\hline 150 & 0.63 & 0.0052 & $q_{e}=0.0052 C_{e}^{0.63}$ & 0.652 & 1.52 & 0.0031 & $q_{e}=0.0031 C_{e}^{1.52}$ & 0.913 \\
\hline$\infty$ & 0.63 & 0.0052 & $q_{e}=0.0052 C_{e}^{0.63}$ & 0.773 & 1.03 & 0.0037 & $q_{e}=0.0037 C_{e}^{1.031}$ & 0.658 \\
\hline
\end{tabular}

Table 6

Selectivity with MCM-41 and Ni/MCM-41 varying the Si/Al ratio at different concentrations of N.

\begin{tabular}{|c|c|c|c|c|c|c|c|c|c|c|}
\hline \multirow[b]{2}{*}{ Ratio Si/Al } & \multicolumn{5}{|c|}{ MCM-41 ppm N } & \multicolumn{5}{|c|}{ Ni/MCM-41 ppm N } \\
\hline & 50 & 100 & 150 & 200 & 250 & 50 & 100 & 150 & 200 & 250 \\
\hline 5 & 60 & 31 & 28 & 25 & 22 & - & 32 & 33 & 23 & 11 \\
\hline 16 & 173 & 81 & 59 & 43 & 42 & 38 & 61 & 47 & 32 & 15 \\
\hline 60 & 391 & 234 & 128 & 96 & 77 & 176 & 256 & 115 & 41 & 27 \\
\hline 150 & 912 & 972 & 634 & 320 & 137 & 474 & 420 & 146 & 96 & 33 \\
\hline$\infty$ & 13,390 & 3,623 & 3,028 & 488 & 203 & 3,500 & 1,627 & 695 & 175 & 51 \\
\hline
\end{tabular}

$\mathrm{Si} / \mathrm{Al}$ ratio showed the higher surface and at low $\mathrm{Si} / \mathrm{Al}$ diminished the specific surface, and $\mathrm{NH}_{3}$-TPD and NMR show that at $\mathrm{Si} / \mathrm{Al}=5$ and 16 have higher acid sites than another $\mathrm{Si} / \mathrm{Al}$ ratio. The modification successfully added small amounts of Ni that did not collapse the pore structure but increased the density of surface (acidic).

From the adsorption results with MCM-41 as adsorbent, the highest removal of $\mathrm{N}$ was at low concentration and high $\mathrm{Si} / \mathrm{Al}$ ratio with both adsorbents, meanwhile, considering the $\mathrm{S}$ the highest removal was obtained at low $\mathrm{Si} / \mathrm{Al}$ ratio (5 and 16 ), this means that the $\mathrm{S}$ removal capacity depended strongly on the acid sites. Regarding the Q adsorption the isotherm of Langmuir for $\mathrm{Si} / \mathrm{Al}=150$ and $\infty$ ratios assume the formation of a few adsorption layers and slightly acidic lowest acidity, at low $\mathrm{Si} / \mathrm{Al}=5,16$ and 60 ratio the Freundlich model was adjusted, thus we have heterogeneous surface non-ideal and reversible adsorption. Moreover, with the Freundlich isotherm was adjusted for the DBT, indicating that the adsorption is a favorable process and multilayer adsorption, with $1 / \mathrm{n}<1$ indicating nonlinearity degree of adsorption, possible chemical process.

On the other hand, when using the adsorbent Ni/MCM-41, almost all ratio the Langmuir model was adjusted, and the Freundlich model was adjusted only with the $\mathrm{Si} / \mathrm{Al}=5$ value, showing lower adsorption of the $\mathrm{Q}$. Moreover, the value $1 / \mathrm{n} \approx 1$ indicate that the adsorption is a favorable process and multilayer adsorption. The adsorption of $\mathrm{Q}$ over MCM-41 adsorbents at high $\mathrm{Si} / \mathrm{Al}$ ratio is selective in comparison with $\mathrm{Ni} / \mathrm{MCM}-41$, but when considering DBT, the specific interactions between this molecule and metal ions involving acid-base interactions and $\pi$-complexation adsorption mechanism between $\mathrm{S}$ and metal ion, is the main factor enhancing the adsorption over Ni/MCM-41 at low $\mathrm{Si} / \mathrm{Al}$ ratio. Besides, the adsorption kinetic can be illustrated by the pseudosecond-order model for both sorbents. Also, these materials were found to be found to be promising adsorbents for Q and DBT capture. Lastly, the selectivity MCM-41 with $\mathrm{Si} / \mathrm{Al}=\infty$ shows the highest $(\mathrm{N} / \mathrm{S})$ selectivity of 13,390 at $50 \mathrm{ppmw} \mathrm{N}$ compared to another $\mathrm{Si} / \mathrm{Al}$ ratio, for example at $250 \mathrm{ppmw}$ N. For future tests, the effect of sorbent regeneration on the performance of the system over multiple cycles should be investigated.

\section{Acknowledgements}

J. C. García-Martínez would like at the Programa para el Desarrollo Profesional Docente (PRODEP) from México.

\section{References}

[1] G.W. Huber, A. Corma, Angew. Chem. Int. Ed. 46 (2007) 7184-7201.

[2] Y.M. Isa, E.T. Ganda, Renew. Sustain. Energy Rev. 81 (2018) 69-75.

[3] I. Naboulsi, B. Lebeau, C.F.L. Aponte, S. Brunet, M. Mallet, L. Michelin, M. Bonne, C. Carteret, J.-L. Blin, Appl. Catal. A Gen. 563 (2018) 91-97.

[4] E. Ito, J.A. Rob van Veen, Catal. Today 116 (2006) 446-460.

[5] R.T. Yang, A.J. Hernández-Maldonado, F.H. Yang, Science 301 (2003) 79-80.

[6] A. Samokhvalov, B.J. Tatarchuk, Catal. Rev.: Sci. Eng. 52 (2010) 381-410.

[7] G.C. Laredo, P.M. Vega-Merino, F. Trejo-Zárraga, Jesús Castillo, Fuel Process. Tech. 106 (2013) 21-32.

[8] J.H. Kim, X. Ma, A. Zhou, Ch. Song, Catal. Today 111 (2006) 74-83.

[9] Y. Shen, P. Li, X. Xub, H. Liu, RSC Adv. 2 (2012) 1700-1711.

[10] J. Rui, F. Liu, R. Wang, Y. Lu, X. Yang, Molecules 22 (2017) 305-317.

[11] Y. Zua, Y. Qina, X. Gaoc, H. Liuc, X. Zhanga, J. Zhanga, L. Song, Appl. Catal. B: Environ. 203 (2017) 96-107.

[12] Z.Y. Zhang, T.B. Shi, C.Z. Jia, W.J. Ji, Y. Chen, M.Y. He, Appl. Catal. B: Environ. 82 (2008) $1-10$.

[13] J. Liao, Y. Zhang, L. Fan, L. Chang, W. Bao, Ind. Eng. Chem. Res. 58 (2019) 4572-4580.

[14] T.A. Saleh, K.O. Sulaiman, S.A. AL-Hammadi, H. Dafalla, G.I. Danmaliki, J. Clean. Prod. 154 (2017) 401-412.

[15] M. Almarri, X. Ma, C. Song, Energy Fuels 23 (2009) 3940-3947.

[16] S.K. Thaligari, V.Ch. Srivastava, B. Prasad, Clean Tech. Environ. Policy 18 (2016) 1021-1030.

[17] D. Rameshraja, V.Ch. Srivastava, J.P. Kushwaha, I.D. Mall, Chem. Eng. J. 181-182 (2012) 343-351.

[18] J.A. Arcibar-Orozco, J.R. Rangel-Mendez, Chem. Eng. J. 230 (2013) 439-446.

[19] S.K. Thaligari, S. Gupta, V.Ch. Srivastava, B. Prasad, Indian J. Chem. Technol. 25 (2018) 522-530. 
[20] S. Jin, Q. Yue, T. Meng, H. Zhang, N. Jiang, M. Jin, R. Zhang, J. Porous Mater. 24 (2017) 1697-1704.

[21] F. Subhan, B.S. Liu, Chem. Eng. J. 178 (2011) 69-77.

[22] S. Shahriar, X. Han, H. Lin, Y. Zheng, Int. J. Chem. React. Eng. 14 (4) (2016) 823-830.

[23] J.M. Palomino, D.T. Tran, J.L. Hauser, H. Dong, S.R.J. Oliver, J. Mater. Chem. A Mater. Energy Sustain. 2 (2014) 14890-14895.

[24] J.L. Hauser, D.T. Tran, E.T. Conley, J.M. Saunders, K.C. Bustillo, S.R.J. Oliver, Chem. Mater. 28 (2016) 474-479.

[25] J. You, H. Song, J. Zhang, Ch. Chen, F. Han, Fuel 241 (2019) 997-1007.

[26] S.A. Shahriar, H. Lin, Y. Zheng, Ind. Eng. Chem. Res. 51 (2012) 14503-14510.

[27] J.C. García-Martínez, H.A. González Uribe, M.M. González-Brambila, J.A. ColínLuna, Y.E. Escobedo-García, A. López-Gaona, L. Alvarado-Perea, Catal. Today 305 (2018) 40-48.

[28] J.C. García-Martínez, C.R. Tapia Medina, M.M. González-Brambila, A.K. MedinaMendoza, J.A. Colín-Luna, Int. J. of Chem. Reactor Eng. 2018 (2017) (2017) 0238.

[29] L. Alvarado Perea, T. Wolff, P. Veit, L. Hilfert, F.T. Edelmann, C. Hamel, A. SeidelMorgenstern, J. Catal. 305 (2013) 154-168.

[30] M. Yonemitsu, Y. Tanaka, M. Iwamoto, Chem. Mater. 9 (1997) 2679-2681.

[31] J.C. García-Martínez, H.A. González-Uribe, M.M. González-Brambila, N.G. Flores del Río, A. López-Gaona, L. Alvarado-Perea, J.A. Colín-Luna, Top. Catal. 61 (2018) 1721-1733.

[32] S. Azizian, R.N. Fallah, Appl. Surf. Sci. 256 (2010) 5153-5156.

[33] M. Songolzadeh, M. Soleimania, M.T. Ravanchi, Microporous Mesoporous Mater. 274 (2019) 54-60.

[34] C.T. Kresge, M.E. Leonowicz, W.J. Roth, J.C. Vartuli, J.S. Beck, Nature 359 (1992) $710-712$.

[35] J.S. Beck, J.C. Vartuli, W.J. Roth, M.E. Leonowicz, C.T. Kresge, K.D. Schmitt, C.T.W. Chu, D.H. Olson, E.W. Sheppard, J. Am. Chem. Soc. 114 (27) (1992) 10834-10843.

[36] K.S.W. Sing, D.H. Everett, R.A.W. Haul, L. Moscou, R.A. Pierotti, J. Rouquerol, T. Siemieniewska, Pure Appl. Chem. 57 (4) (1985) 603-619.

[37] A. Corma, V. Fornes, M.T. Navarro, J. Perez-Pariente, J. Catal. 148 (2) (1994) $569-574$.
[38] M. Hartmann, A. Pöppl, L. Kevan, J. Phys. Chem. 100 (23) (1996) 9906-9910.

[39] H. Kosslick, G. Lischke, G. Walther, W. Storek, A. Martin, R. Fricke, Microporous Mater. 9 (1-2) (1997) 13-33.

[40] H. Kosslick, G. Lischke, B. Parlitz, W. Storek, R. Fricke, Appl. Catal. A Gen. 184 (1) (1999) 49-60.

[41] T. Lehmann, T. Wolff, C. Hamel, P. Veit, B. Garke, A. Seidel-Morgenstern, Microporous Mesoporous Mater. 151 (2012) 113-125.

[42] M. Magi, E. Lippmaa, A. Samoson, G. Engelhardt, A.R. Grimmer, J. Phys. Chem. 88 (8) (1984) 1518-1522.

[43] G. Engelhardt, D. Michel, High-Resolution Solid-State NMR of Silicates and Zeolites, Page Bros., Norwich, Great Britain, (1987).

[44] K.R. Kloetstra, H.W. Zandbergen, H. Bekkum, Catal. Lett 33 (1-2) (1995) 157-163.

[45] F. Subhan, Z. Yan, P. Peng, M. Ikram, S. Rehman, J. Hazard. Mater. 270 (2014) 82-91.

[46] J.M.P.F. Silva, E.B. Silveira, A.L.H. Costa, C.O. Veloso, C.A. Henriques, F.M.Z. Zotin, M.L.L. Paredes, R.A. Reis, S.S.X. Chiaro, Ind. Eng. Chem. Res. 53 (2014) 16000-16014.

[47] I. Ahmed, M. Tong, J.W. Jun, C. Zhong, S.H. Jhung, J. Phys. Chem. C 120 (2016) 407-415.

[48] J.A. Arcibar-Orozco, A.A. Acosta-Herrera, J.R. Rangel-Méndez, J. Cleaner Prod. 218 (2019) 69-82.

[49] A.W. Adamson, A.P. Gast, Physical Chemistry of Surfaces, sixth ed., WileyInterscience, New York, 1997.

[50] K. Chang Hyun, S. Hirn-Ill, P. Jong-Ho, H. Sang-Sup, K. Jong-Nam, Korean J. Chem. Eng. 24 (6) (2007) 1124-1127.

[51] K. Vijayaraghavan, T.V.N. Padmesh, K. Palanivelu, M. Velan, J. Hazard. Mater. B133 (2006) 304-308.

[52] R.G. Parr, R.G. Pearson, J. Am. Chem. Soc. 105 (1983) 7512-7516.

[53] S. Velu, Ch. Song, M.H. Engelhard, Y.H. Chin, Ind. Eng. Chem. Res. 44 (15) (2005) 5740-5749.

[54] J.A. Colín-Luna, G.E. Zamora-Rodea, A.K. Medina-Mendoza, L. Alvarado-Perea, C. Ángeles-Chávez, J. Escobar, J.G. Pacheco-Sosa, J.C. García-Martínez, Catal. Today (2019) In Press. 